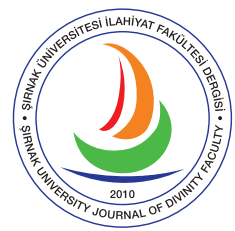

Şırnak University Journal of Divinity Faculty Vol.: 11, Issue: 24, June 2020

e-ISSN 2667-6575

\title{
Son Dönem Osmanlı Şeyhlerinden Ken'ân Rifâî: Hayatı, Eserleri ve Tasavvuf Anlayışı
}

A Late Ottoman Sheikh Ken'ân Rifầ: His Life, Works and Understanding of Sufism

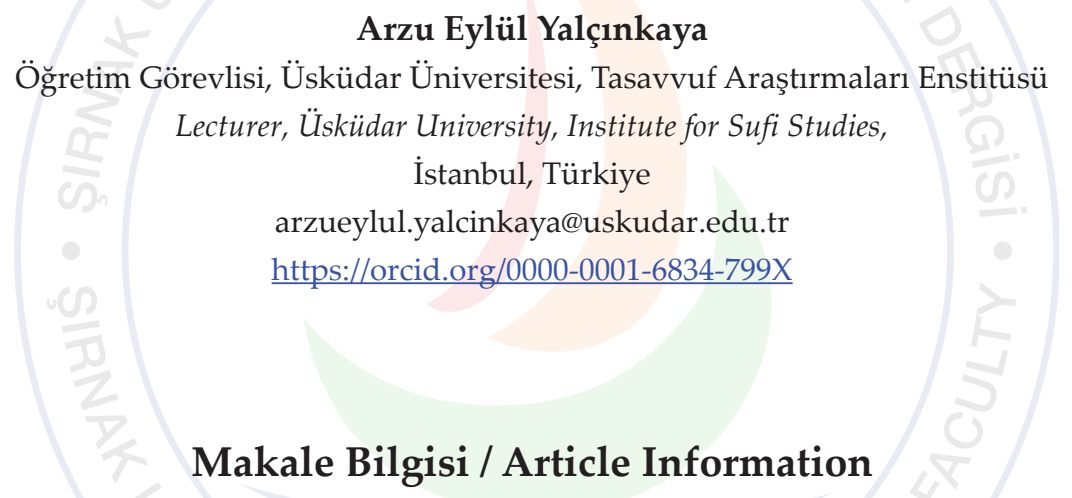

Makale Türü / Article Types: Araştırma Makalesi / Research Article

Geliş Tarihi / Received: 30 Kasım / November 2020

Kabul Tarihi / Accepted: 21 Şubat / February 2020

Yayın Tarihi / Published: 15 Haziran / June 2020

Cilt / Volume: 11 Sayı / Issue: 24 Sayfa / Pages: 98-128

Atıf / Cite as: Yalçınkaya, Arzu Eylül. "Son Dönem Osmanlı Şeyhlerinden Ken'ân Rifâi: Hayatı, Eserleri ve Tasavvuf Anlayışı [A Late Ottoman Sheikh Ken'ân Rifâ̂: His Life, Works and Understanding of Sufism]". Şırnak Üniversitesi Illahiyat Fakültesi Dergisi - Şırnak University Journal of Divinity Faculty 11/24 (June 2020), 98-128.

https://doi.org/10.35415/sirnakifd.653398

Etik Beyanı / Ethics Declaration: Bu makalede bilimsel araştırma ve yayın etiği ilkelerine riayet edilmiştir. Makale etik izin gerektirmeyen bir çalışma olup en az iki hakem tarafından incelenmiş ve intihal içermediği teyit edilmiştir / In this article, the principles of scientific research and publication ethics are respected. The article is a study that does not require ethical permission. It has been reviewed by at least two referees and was confirmed that it did not contain plagiarism.

Copyright ( Published by Şırnak Üniversitesi, İlahiyat Fakültesi / Şırnak, Türkiye (Şırnak University, Faculty of Divinity, Şırnak, 73000 Turkey). 


\section{Öz}

Ken'ân Rifâî, 20. yüzyılın önemli sûfi şeyhlerinden birisidir. Tasavvufî görüşlerinde tevhid ve aşk vurgusu öne çıkan şeyh Ken'ân Rifâî, meşrebinde sahv unsuru galip gelen dengeli ve orta yolu takip etmiş bir sûfî portresi çizmektedir. Söz konusu denge hâli, onun din ve tasavvuf anlayışında da kendisini hissettirmektedir. Bu makalede, Osmanlı son dönem sûfî ve maârifçilerinden Ken'ân Rifâî'nin hayatı ve tasavvuf anlayışı ortaya konulacaktır. Bunun için öncelikle onun hayatı ve tasavvuf eğitiminin ayrıntıları hakkında bilgi verilecektir. Şeyh Ken'ân Rifâî, 1869 yılında Selânik'te dünyaya geldi. Filibe Hânedanı'na mensup olan Rifâî, 1876 Bulgar isyânı sırasında ailesi ile birlikte İstanbul'a gelerek Fatih semtine yerleşti. Galatasaray Lisesi'nden mezuniyetinin ardından, Bâbıâli'de görev aldıktan sonra, Maârif Nezâreti bünyesindeki kurumlarda çalışmaya başladı. Balıkesir'de başlayan memuriyet hayatı boyunca, Anadolu'dan Balkanlara, İstanbul'dan Medine'ye kadar birçok vilayette Maârif müdürlüğü, idarecilik ve müfettişlik gibi vazifelerde bulunan Ken'ân Rifâî, bu süre zarfında iki tarikattan seyr ü sülûkunu tamamladı. Filibeli Ethem Efendi'den Kadiri icazeti ve Medine Şeyhü'l-Meşâyıhı Hamza er-Rifâî'den, Rifâî icazeti alarak, 1908 yılından itibaren Fatih semtindeki Ümmü Ken'ân Dergâhında resmi olarak şeyhlik görevine başladı. Meclis-i Meşâyıh'a bağlı bir şeyh olarak on yedi yıl boyunca irşad faaliyetlerine devam eden Rifâî, yazdığ 1 eserler ve bestelediği ilahilerle tasavvuf literatürüne ve tekke kültürüne önemli katkilarda bulundu. Ken'ân Rifâî, tekkelerin ilgası ile ilgili kararı, Hakk'ın bir tecellisi olarak kabul ederek 1925 yılında tekke faaliyetlerine son vermiştir. Ken'ân Rifâî Osmanlı Devleti'nin geleneksel ve modern eğitim kurumlarında yetişmiş bir eğitimci ve mutasavvıftır. Onun hayatı ve tasavvuf anlayışını incelemek, Osmanlı Devleti'nin son döneminde tasavvuf hareketlerini anlamaya da imkân vermektedir.

Anahtar Kelimeler: Tasavvuf, Osmanlı Devleti, Ken'ân Rifâî, Maârif, Rifâîlik.

\section{Abstract}

Sheikh Ken'ân Rifâî, who outstands the unity and love in his Sufi views, draws a portrait of a Sufi that has a conscious personality and following a balanced and middle way. This state of balance makes itself felt in Rifâî's understanding of religion and Sufism. In this article, I will examine the understanding of Sufism and life of Ken'ân Rifâî, one of the Late Ottoman Sufis and educators. Ken'ân Rifâî, a member of Plovdiv Dynasty, was born in Salonika, in 1867. During the Bulgarian ethnic rebellion against the Ottoman Empire, Ken'ân Rifâî moved to Istanbul with his family in 1876. Having graduated from Galatasaray High School, he worked for a short time at governmental offices of Sublime Porte. He then became a high-ranking administrator and teacher under the Ministry of Education. He was appointed in various cities of the Empire from Anatolia to the Balkans such as Balıkesir, Adana, Bitola, Kosovo, and Trabzon. Ken'ân Rifâî received his Qadiri license from Sheikh Ethem Efendi and his Rifâî license from Sheikh Hamza Efendi. Upon his return to Istanbul, he built a Sufi lodge adjacent to his mansion and became an official sheikh registered in the Ottoman Council of the Sheikh in 1908. Ken'ân Rifâî continued to train his followers for seventeen years. With his written work and compositions, he had a significant contribution to the literature and culture of the Sufi tradition. He closed his lodge in 1925 with the Republican ban of Sufi orders without any opposition as he considered it as the will of God. Ken'ân Rifâi is an educator and sheikh of the $20^{\text {th }}$ century. It is important to examine Rifâî's life and understanding of Sufism in order to better reflect on the Late Ottoman Sufi movements.

Keywords: Sufism (Tasawwuf), Ottoman Empire, Ken'ân Rifâî, Education, Rifā iyya. 


\section{Extended Abstract}

Sheikh Ken'ân Rifâi, who was famous for prioritizing unity and love in his Sufi views, led and promoted a God-concsious and balanced lifestyle, which informed his understanding of religion and Sufism. During the Bulgarian ethnic rebellion against the Ottoman Empire, Ken'ân Rifâî moved to Istanbul with his family in 1876. After graduating from Galatasaray High School in 1988, he attended the law school for a short time while working in the governmental offices of Sublime Porte. However, his lifetime career took off in the education sector, as he became a high-ranking administrator and teacher working under the Ministry of Education. He was appointed in various cities of the Empire from Anatolia to the Balkans such as Balikesir, Adana, Bitola, Kosovo, and Trabzon. As the regional director of education, he was responsible for building new schools, the application of new curriculum and modern education methods, overseeing the new teacher appointments and inspecting the schools. During his first post in Balikesir in 1889, Ken'ân Rifâi also started practicing Sufism under the guidance of his mother's Sufi master, namely the Qadiri Sheikh Edhem Efendi who was a civil sheikh operating without a formal lodge. Ken'ân Rifâî received his lodge-based Sufi training in Madina where he was appointed as the principal of the new Hamidian School in 1901. He joined the Rifai order and received his licence from the Rifai sheikh Hamza Efendi. Upon his return to Istanbul, he built a Sufi lodge adjacent to his mansion and became an official sheikh registered in the Ottoman Council of the Sheikh in 1908. He closed his lodge in 1925 with the Republican ban of Sufi orders without any opposition as he considered it as the will of God. He observed that the majority of lodges had lost both of their spiritual credentials and deep knowledge of the Sufi philosophy. He famously said that "one day the lodges will be opened, but in the form of modern academic institutions." The lodge of Ken'ân Rifâi observed the major functions of the centuries-old traditions of the typical Sufi lodges. Although Ken'ân Rifâî mainly adopted the Rifâî way of Sufism, at times, he also practiced Qadiri and Shadhili methods in which he was also licensed. His house and lodge became an important center frequented by the religious and Sufi authorities of his time. Among his followers, there were even several Ottoman Sheikh-ul-Islams. Ken'ân Rifâî's writing career started at an early age following his graduation from Galatasaray High School. His first publication in 1891 was a biology textbook for high school students, titled Muktezâ-y Hayât. During his career as a teacher, he wrote many articles on education 
and pedagogy in various newspapers. He also penned many poems and translated works from various languages. The peak of his writing career coincided with the time when he formally established his Sufi lodge in Istanbul. He published four works in this period. However, in his prime age as a writer, the Sufi lodges were officially shut down and Sufi publications were curtailed. Ken'ân Rifâî maintained his studies at home by working on the exegeses of Masnavi. His notebooks and oral discourses were posthumously published as sohbet books. There are still many unpublished works of Ken'ân Rifâî that await being edited and published.

Ken'ân Rifâi followed the traditional Sufi doctrine of religion as expressed through the concepts of şeriât (shari'a), tarikat (tariqa), and hakikat (truth). Observing the external dimensions of religion, shari'a, was important for the maintenance of material and spiritual life. However, one should not have stayed at this initial level, but must have strove for reaching to the level of Truth. Based on the hadith of Gabriel that formulated religion with the maxim of Islam, faith (iman), and excellence (ihsan), Ken'ân Rifâi interpreted all the religious issues through the lens of this tripartite definition of religion. Like Serrac, he identified Sufism with ihsan. To put it in other words, Sufism showed the ways in which one could worship as if he could see God and could attain the consciousness of God's ever-watchfulness. In this article, the understanding of Sufism and life of Ken'ân Rifâî, one of the late Ottoman Sufis and educators, will be presented. For this purpose, the details about Rifai's life and Sufism education life will be represented. Rifâi is an educator and sheik who was educated by traditional and modern educational institutions of the Ottoman Empire. It is important to examine Rifâi's life and understanding of Sufism in order to better understand the Late Ottoman Sufi movements. 


\section{GİRIŞ ${ }^{1}$}

20. yüzyılda yaşamış önemli sûfilerden biri olan Ken'ân Rifâi (öl.1950) mânevi eğitimini ilk olarak annesi Hatice Cenân Hanım'dan almıştır. İlk tasavvuf terbiyesini Kadiri-Üveysî meşreb ve sivil giyimli bir şeyh olan Filibeli Şeyh Ethem Efendi'den alan Rifâ̂i, Balıkesir'de bulunduğu sırada (1889) henüz yirmi yaşında iken Kadiri usûlü ile seyrü sülûkunu tamamlamıştır. Rifâî, ilerleyen yıllarda İdâdi-i Hamîdî müdürü olarak Medine'de bulunduğu dönemde, Medine Şeyhü'l-Meşâyıhı Hamza er-Rifâi'ye hizmet ederek, bu zâttan Rifâî icâzetnâmesi almıştır. Ken'ân Rifâî, İstanbul'a kesin olarak yerleştikten sonra (1904) Fatih'teki konağının bahçesinde inşâ ettirdiği Ümmü Ken'ân Dergâhı'nda tekke şeyhliğine başlamış; tekke ve zâviyelerin ilgasına kadar on yedi yıl burada resmi olarak şeyhlik görevine devam etmiştir. Şeyh Ken'ân Rifâî tasavvuf alanındaki eserleriyle literatüre yeni eserler kazandırırken; bestelediği manzûmeleriyle de tekke kültürüne önemli katkılarda bulunmuştur. ${ }^{2}$ Tasavvuf anlayışında tevhid ve aşk vurgusu öne çıkan Rifâî, meşrebinde sahv unsuru galip gelen dengeli ve orta yolu takip etmiş bir mutasavvif portresi çizmektedir. Bu makalede Ken'ân Rifâ̂i'nin hayatı, eserleri, tekke faaliyetleri ve tasavvuf anlayışı hakkında bilgi verilecektir.

\footnotetext{
${ }^{1}$ Bu çalışma "Kenan Rifâi: Hayatı, Eserleri ve Tasavvuf Anlayışı” başlıklı doktora tezi esas alınarak hazırlanmıştır / This article is extracted from doctorate dissertation entitled “Ken'ân Rifâî: His Life, Works and Understanding of Sufism (PhD Dissertation, Bursa Uludağ University, Bursa/Turkey, 2020).

2 Ken'ân Rifâî'nin hayatı ve tasavvufî görüşleri hakkında bk. Mustafa Tahralı, "Ken'ân Rifầ", Türkiye Diyânet Vakfı İslâm Ansiklopedisi (İstanbul: TDV Yayınları, 2002), 25/254255; Arzu Eylül Yalçınkaya, Ken'ân Rifâî́nin Mesnevî Sohbetleri (İstanbul: İstanbul Üniversitesi, Sosyal Bilimler Enstitüsü, Yüksek Lisans Tezi, 2012), 3-36.
} 


\section{KEN'ÂN RIFF̂̂̂' NİN HAYÂTI VE ESERLERI}

\subsection{Ken'ân Rifâî'nin Hayâtı}

Yirminci yüzyılın önemli şeyhlerinden biri olan Ken'ân Rifâî (öl. 1950), 1867 tarihinde Selânik'te dünyaya gelmiştir. ${ }^{3}$ Hicaz Vilâyeti Posta ve Telgraf Baş Müdürü Hacı Abdülhalim Bey ile Kafkas asıllı Hatîce Cenan Hanım'ın oğludur. Dedesi Hacı Hasan Bey, Filibe hanedanına mensup olup bir müddet Alâiye Kaymakamlığı'nda bulunmuştur. Ken'ân Rifâi' nin mensup olduğu Filibe hanedanı bölgede geçmişi oldukça eskiye dayanan nüfuzlu bir ailedir. Çocukluk yıllarını Filibe'de dedesinin çiftliğinde geçiren Rifâî, burada Rumeli'nin henüz kendi geleneği içerisinde yaşadığı hayatın ayrıntılarını görme imkânını yakalamış; Osmanlı Devleti'nin söz konusu topraklardan çekilmeden önceki günlerini tecrübe etmiştir. 1876 Bulgaristan ayaklanmasının ardından ailesiyle birlikte İstanbul'a yerleşen Rifâî, hemen akabinde Galatasaray Mekteb-i Sultânîsi'ne kaydını yaptırarak 1888'deki mezuniyetine kadar tahsiline devam etmiştir.

Ken'ân Rifâî'nin çok küçük yaşta girdiği Galatasaray Mekteb-i Sultânîsi'ndeki eğitiminin mâhiyetini belirlememiz, onun düşünce dünyasının inceliklerine vâkıf olabilmek ve tasavvufî şahsiyetini şekillendiren âmilleri iyi değerlendirebilmek açısından önemlidir. Galatasaray Sultânîsi, 19. yüzyılda devlet hizmetinin üst kademelerinde görevlendirilmek üzere yönetici yetiştirmeye yönelik açılan kurumlar içerisinde en önemlilerden biriydi. ${ }^{4}$ Lise düzeyinde eğitim veren bu kurum, Osmanlıcılık ideolojisinden besleniyor ve takip ettiği program ile yeni bir Osmanlı bireyi yaratmayı hedefliyordu. Farklı etnik grupların bir arada eğitim aldığı okul, milletlerarası eşitliğin ilk tatbik sahalarından biri durumundaydı. Galatasaray Sultânîsi, Osmanlı Devleti'nin Batı'ya açılan bir penceresi olduğu kadar, öğrencilerini formel manada Doğu kültür ve geleneğiyle de tanıştıran devrin en etkili kurumlarından biriydi. ${ }^{5}$ Zira lise, yalnızca Batı lisanlarını değil, İmparatorluğun Doğu'dan Batı'ya uzanan kültür coğrafyasında görülen birçok klasik dili de talebelerine öğretiyordu. Arapça, Farsça, Fransızca, Bulgarca, Ermenice, Rumca, Latince bu dillerden bazılarıdır.

3 Yalçınkaya, Ken'ân Rifâ̂̀'nin Mesnevî Sohbetleri, 296-300; Mehmet Demirci, “Ken'ân Rifâî'nin Mânevî Dünyâsı", Bir Yirminci Yüzyıl Münevveri Ken'ân Rifâ̂̀ Sempozyumu Bildiri Kitabı, ed. Fulya Bayraktar (İstanbul: Cenân Eğitim Kültür ve Sağlık Vakfı Neşriyâtı, 2015), 61-68.

4 Adnan Şişman, "Galatasaray Mekteb-i Sultânîsi", Türkiye Diyânet Vakfı İslâm Ansiklopedisi (İstanbul: TDV Yayınları, 2002), 13/323.

5 İlhan Tekeli, “Osmanlı İmparatorluğu'ndan Günümüze Eğitim Kurumlarının Gelişimi”, Cumhuriyet Dönemi Türkiye Ansiklopedisi (İstanbul: İletişim Yayınları, 1983), 3/657. 
II. Abdülhamid dönemi eğitim uygulamaları ${ }^{6}$ nedeniyle Sultânî müfredatında akaid ve ahlâk bilgisine yönelik dersler de bulunmaktaydı. Recâizâde Mahmud Ekrem (öl. 1914), Muallim Nâci (öl. 1893), Muallim (Ahmed) Feyzi (öl. 1910), Ali Suâvi (öl. 1878) ve Mehmet Zihnî Efendi (öl. 1919) Ken'ân Rifâî'nin Sultânî'deki hocaları arasındaydı.7 Ken'ân Rifâî, Sultânî eğitimi sırasında ileri derecede Arapça, Farsça, Fransızca ve Almanca öğrenmiş; ${ }^{8}$ farklı düşünce geleneklerine mensup hocalardan aldığı dersler nedeniyle Doğu ve Batı düşünce dünyasına aşinalık kesbetmiştir. Rifâ̂' nin Sultânî'de kazandığı donanımı, eğitimciliği ve tekke şeyliği sırasında etkili bir şekilde kullandığı görülmektedir. ${ }^{9}$

Ken'ân Rifâî, Galatasaray Sultânisi'nden mezuniyetinin ardından kısa bir süre Bâbıâli kalemlerinde çalıştıktan sonra Mâ̂rif Nezâreti'nde göreve başlamış, ${ }^{10}$ Bâbıâli'de bulunduğu kısa dönem hariç çalışma hayatı boyunca öğretmenlik, maârif müdürlüğü, müfettişlik gibi maârif vazifelerinde bulunmuştur. Ken'ân Rifâî'nin memuriyet yılları farklı şehirlerde geçmiş ve yetişkinlik hayatı büyük ölçüde maârif görevleriyle şekillenmiştir. Rifâî

${ }^{6}$ II. Abdülhamid döneminde genelde Sultânîler ve özelde Galatasaray Sultânîsi'ndeki eğitim hakkında bilgi için bk. Esmâ İgüs, II. Abdülhamid Dönemi Eğitim Sistemi, Eğitim Yapıları ve Askeri Rüşdiyeler (İstanbul: Yıldız Teknik Üniversitesi, Sosyal Bilimler Enstitüsü, Doktora Tezi, 2008), 68-71; Bayram Kodoman, Abdülhamid Devri Ĕ̆itim Sistemi (Ankara: Türk Tarih Kurumu Basımevi, 1988), 133-136.

7 Sâmiha Ayverdi vd., Ken'an Rifâ̂ি ve Yirminci Yüzyılın Işı̆̆̆ıda Müslümanlık (İstanbul: Kubbealtı Neşriyâtı, 2003), 24-25.

8 Arapça ve Farsça dersleri almaya ve her iki lisandan da Türk diline tercümeler yapmaya Galatasaray eğitimiyle başlamıştır. Arapça ve Farsçadan Türkçeye tercümeler yaptı̆̆ 1 gibi, aynı şekilde Türkçe metinleri de bu dillere kuvvetli bir şekilde çevirebilmektedir. Galatasaray diplomasında, Farsça ve Arapça dilbilgisi ile çeviri derslerinin notları oldukça yüksek görünmektedir. İsmet Binark, Dost Kapısi: Ezel ve Ebed Arasında Ken'ân (Rifâ̂) Büyükaksoy (İstanbul: Cenan Eğitim, Kültür ve Sağlık Vakfı Neşriyâtı, 2005), 41; Öğretmenlik yıllarında, Fransızca dersinde faydalanılması için hadisleri Fransızcaya çevirdiği görülmektedir. Yine aynı ders kapsamında Mesnevî beyitlerini de Fransızcaya ve Türkçeye çevirmektedir. Arapçası kuvvetlidir. Arapça şiirler yazmaktadır. Arapça şiirleri için bk. Ken'ân Rifâî, Illâhiyât-ı Ken'ân: İlâhî ve Manzûmeler, haz. Mustafa Tahralı (İstanbul: Cenan Eğitim, Kültür ve Sağlık Vakfı Neşriyâtı, 2013), 83-186.

9 Demirci'nin ifadesiyle "Ken'ân Rifâî Galatasaray Lisesi'nde modern Batı düşüncesinin ipuçlarını öğrenmiştir." Ancak yukarıdaki izahlardan anlaşılacağı üzere Rifâî, İslâm geleneğini anlamaya imkân verecek dil ve din eğitimini de ilk etapta Galatasaray Sultânîsi eğitimine borçludur. bk. Mehmet Demirci, Ken'ân Rifâ̂̀ Yazıları (İstanbul: Cenan Eğitim, Kültür ve Sağlık Vakfı Neşriyâtı, 2016), 24; O dönemde okutulan dersler genel olarak Türkçe, Fransız dili ve edebiyatı, ahlâk ve âdap, Latince, Grekçe, Osmanlı tarihi, genel tarih, Osmanlı coğrafyası, genel coğrafya, matematik, kozmografya, mekanik, fizik, kimya, tabiat bilgisi, hukuk, mülkî idare, hitabet ve edebiyat, hat ve resim, muhasebe, defter tutma gibi derslerdir. Ken'ân Rifâ̂̀'nin Mâ̂rif Müdürlü̆ğü ve öğretmenlik yaptığı dönemde yukarıda adı geçen derslerin birçoğunu okuttuğu Maârif Nezâreti kayıtlarında geçmektedir. İlgili belge için bk. BOA, DH.SAID., 72.405.

${ }^{10}$ Demirci, Ken'ân Rifâî Yazıları, 16. 
1889 yılında Balıkesir Karesi İdâdîsi müdürlüğüne tayin edilmiştir. Daha sonra sırasıyla Adana, Manastır, Kosova, Trabzon Maârif müdürlüklerinde bulunmuş; İstanbul'da Numûne-i Terakkî lisesi müdürlüğünün ardından Medine'ye tayin edilmiştir. İdâdî-i Hamidi müdürü olarak dört yıla yakın Medine'de hizmet eden Rifâî, 1904 yılında İstanbul'a dönmüş ve vefatına kadar (1950) İstanbul'da ikamet etmiştir. 1908'de, Fatih'teki konağının avlusunda inşa ettirdiği Ümmü Ken'ân Dergâhı'nda Meclis-i Meşâyıh'a bağlı bir şeyh olarak hizmet etmeye başlayan Rifâî, Cumhuriyet'in ilanına kadar bir yandan Maârif Nezâreti bünyesinde memuriyetini yürütürken diğer yandan resmî olarak şeyhlik görevini devam ettirmiştir. Bu genel bilgilendirmeden sonra, onun memuriyet hayatına ve tasavvufî eğitimine daha yakından bakabiliriz.

Ken'ân Rifâî, ilk memuriyet yeri olan Balıkesir Karesi İdâdîsi'nde göreve başladığında okuldaki öğrenci sayısı azdır. Rifâînin bölge halkıyla irtibatları neticesinde, öğrenci sayısı iki yüze ulaşmışıır. ${ }^{11}$ Bununla birlikte tasavvufa intisap ettiği şehir olması bakımından Balıkesir'in, onun hayatında ayrı bir yeri vardır. Rifâî, ilk tasavvuf neşvesini annesi Hatîce Cenan Hanım'dan almış olmakla birlikte resmî anlamda ilk tasavvuf terbiyesini, Balıkesir'de bulunduğu sırada Kadirî-Üveysî meşrep ve sivil giyimli bir şeyh olan Filibeli Şeyh Edhem Efendi'den (öl. 1893[?]) almış ve onun gözetiminde Kadirî usûlü ile seyrü sülûkunu tamamlamıştır. ${ }^{12}$

Ken'ân Rifâî'nin, Balıkesir'deki sülûkundan bahsetmeden önce, annesinden aldığı mânevî-tasavvufî terbiyeden kısaca bahsetmemiz gerekir. Hatîce Cenân Hanım, mizaç olarak tefekkür ve tezekkürü seven, az konuşmayı tercih eden bir kadındır. Filibe'de ikamet ettikleri dönemde, Filibeli Edhem Efendi'ye intisap etmiş ve onunla birlikte Niyâzî̀-i Mısrî Divânı'nı okumuştur. Araz'ın (öl.2009) bildirdiğine göre Hatîce Cenân Hanım yeryüzündeki her zerreyi Hakk tecellisi olarak görmekte ve Hakk sevgisinin ancak halkı sevmekle kemâle ereceğine inanmaktadır. Ahlâkî vasıfları sebebiyle daha yaşarken efsaneleşen ve devrin Râbiası olarak anılan Hatîce Cenan Hanım, mürşidinden aldığ arzusuna muhalefet ederek perhiz üzere yaşamıştır. Oğlu Ken'ân Rifâi’ye verdiği nasihat, ana-oğul arasındaki etkileşimi görmek bakımından kayda değerdir:

${ }^{11}$ Rifâî, Balıkesir'de iken bir yandan mektep müdürlüğü görevini yerine getirirken diğer yandan aynı kurumda Fransızca ve târih-i umûmî dersleri de vermiştir. bk. BOA, DH.SAID., 72.405.

${ }^{12}$ Ken'ân Rifâî, Rehber-i Sâlikîn, Sâliklerin Rehberi, haz. Mustafa Tahralı (İstanbul: Cenan Eğitim, Kültür ve Sağlık Vakfı Neşriyâtı, 2018), 20-21. 
“İnsanları seveceksin, senin içinde tükenmez af, merhamet ve müsâmaha hazineleri var. Onun için yalnız insanları değil, bütün mahlûkatı aynı yorulmaz hız ve aynı tükenmez iştiyakla seveceksin. Sende mevcut cevherleri cömertçe harcamalısın. İnsanları insanlara iştirak ederek, hatalarında ve sevaplarında onlarla bir olarak seveceksin. Doğumları ile çoğalıp ölümleri ile eksilecek kadar onlardan olacaksın. Senin bir insan olarak vazifen, insanların yüzünü müşterek samimi bir gayeye bir ideale çevirmektir ve bunun birçok yolları vardır. Fakat en kestirme, en güzel, en büyük yol aşk ve iman yoludur. Hudutsuz bir insanlık aşkı... beşeriyetin tek selâmet kapısı her zaman budur. İnsan kemâle, beşerîlikten ulûhîliğe, kısacası Allah'a ancak bu yoldan ulaşır."13 Hatîce Cenân Hanım'ın yukarıdaki ifadeleri Yûnus Emre'nin "Yaratılmışı severim yaratan da ötürü" mısralarının bir yorumu mâhiyetindedir. Oğluna tavsiyelerinden anlaşıldığı üzere Hatice Cenân Hanım, Rifầ'nin Anadolu'da yüzyıllardır hâkim olan sevgi ahlâkını yaşaması ve yaşatmasını istemektedir. Bir başka deyişle Ferîduddin Attâr (öl. 618/1221) ve Mevlânâ Celâleddîn-i Rûmî'nin (öl. 672/1273) ilâhî aşk anlayışı, bir annenin sade ve samimi diliyle oğluna aktarılmaktadır. Rifâî, ilerleyen yıllarda aldığı tasavvuf eğitimi ile annesinden aldığı bu prensipleri kuvvetlendirerek kendi tasavvuf anlayışını ortaya koymuştur.

Ken'ân Rifâî'nin Balıkesir'de iken Filibeli Edhem Efendi'nin terbiyesinde Kadirî usûlüne göre seyr ü sülûkunu tamamladığını söylemiştik. Mânevî açıdan son derece verimli geçen bu dönemin öne çıkan iki husûsiyeti vardır: Riyâzet ve mûsikî eğitimi. Edhem Efendi, İstanbul'dan kalkarak genç müridinin yanına gelir ve bir metod dahilinde seyr ü sülûkun çeşitli basamaklarını geçmesi konusunda onu zorlamaya başlar. Böylece riyâzata başlayan Rifâî, burada ikamet ettiği on bir ay boyunca kuru ekmek ve zeytinden ibaret olan bir perhize devam etmiştir. ${ }^{14}$ İlerleyen zamanlarda maddî-mânevî vazifeler için gereken ferâgat, diğergâmlık, irâde kuvveti gibi meziyetlerin bu dönemde yapılan riyâzat vasıtasıyla kuvvetlendiği anlaşılmaktadır. Rifâî

\footnotetext{
${ }^{13}$ Ayverdi vd., Ken'an Rifâî ve Yirminci Yüzyılın Işı̆̆ııda Müslümanlık, 18.

${ }^{14}$ Tasavvuf tarihinde bu tür riyâzatın örnekleri çoktur. Ekmek ve zeytin tasavvuf terbiyesinde kullanılan geleneksel bir perhiz metodudur. Ayverdi bu dönemi değerlendirirken, bu suretle "askariden askari ile yaşamanın zevkini" duyduğunu kaydeder. Bu perhizin, genç bünyenin maddi manevi sınırlarını zorlayarak onu daha ileri bir noktaya taşıdığı söylenebilir. Nitekim riyâzat tasavvufta tahalluk derecesinden tahakkuk ya da tahkik derecesine yükselmenin başlangıcı olmaktadır. Tasavvufta riyâzat türleri ve yeme-içme ile ilgili riyâzatın tekâmül sürecindeki hızlandırıcı rolü için bk. Öncel Demirdaş, "Riyazet Eğitimi ile Gerçekleşen Mânevî Olgunluk", Dinbilimleri Akademik Araştırma Dergisi 11/1 (2011), 79-90; Süleyman Uludă̆, "Riyâzet", Türkiye Diyânet Vakfı İslâm Ansiklopedisi (İstanbul: TDV Yayınları, 2008), 35/143-144.
} 
bu dönemde, yine mürşidi Edhem Efendi'nin emriyle mûsikî tahsiline başlar. ${ }^{15}$ Bir hocadan ders alarak ney meşketmeyi öğrenir. Araz'ın eserindeki anlatımlardan anlaşıldığı üzere genç Rifâî, kısa süre içerisinde bu eğitime cevap vermiş; ney icrasiyla çevresindekileri etkileyecek bir dereceye ulaşmiştır. ${ }^{16}$ Ken'ân Rifâî, ilerleyen yıllarda musiki yönünü kuvvetlendirerek, güfteleri ona ait olan birçok ilâhî bestelemiştir.

Filibeli Ethem Efendi, güzel vasıfları ile Filibe'de ün salmış bir zattır. ${ }^{17}$ Genç, mevzun bir yapıya sahip, melihü'l-vech bir zat olarak tavsif edilen Filibeli Edhem, gizemli bir mizâca sahip olup aşklı, feyzli ve esrarlıdır. ${ }^{18}$ Araz, Edhem Efendi'nin tasavvufi meşrebinde, Şems-i Tebrizi'ye (öl. 645/1247[?]) benzer özelliklerin bulunduğunu kaydetmektedir. ${ }^{19}$ Edhem Efendi'nin, müridlerinin terbiyesiyle bireysel olarak ilgilendiği ve onlara Niyâzî Mısri Divânı'nı okuttuğu bilinmektedir. Rifâî'nin ondan aldığı tasavvufî eğitimin mahiyeti, sohbetlerinde Niyâzî-i Mısrî̀ye yönelik atıflardan takip edilebilmektedir. ${ }^{20}$

Ken'ân Rifâî, Balıkesir'den sonra Adana Maârif Müdürlügü̈nde bulunmuş, burada yerel idarecilerle işbirliği yaparak okul yaptırma konusunda halkı uyandırmaya çalışmıştır. Bu gayeye yönelik olarak Vali Şâkir Paşa ve diğer ileri gelen idarecilerle işbirliği yaptığı ve bölge eğitimi açısından olumlu neticeler aldığı anlaşılmaktadır. ${ }^{21}$ Rifâî’ye, Adana Maârif Müdürlüğü es-

${ }^{15}$ Ancak Ken'ân Rifâî́nin maârif hayatı çoğunlukla İmparatorluğun sınırlarındaki zorlu bölgelerde ve büyük ölçüde art arda gelen çileli tecrübelerle geçmiş görünmektedir. Rifâî'nin, ileride bu tecrübeleri talebelerine aktarırken bu perspektiften ele aldığı görülür: Müridlerinin payına düşen çileyi onlar adına peşinen yüklendiğini kaydetmektedir: "Birçok mürebbîler talebelerini mücâhede, riyâzat ve türlü çilelerle terbiye ederler. Ben ise onların çilelerini kendim çektim." Ayverdi vd., Ken'an Rifâî ve Yirminci Yüzyılın Işı̆̆ıında Müslümanlık, 131; Ken'ân Rifâî́nin Balıkesir dönemi hakkında daha fazla bilgi için bk. Sâmiha Ayverdi, Dost (İstanbul: Kubbealtı Neşriyâtı, 2017), 23.

${ }^{16}$ Araz, Anadolu Evliyaları, 454.

${ }^{17}$ Edhem Efendi ile ilgili arşiv kayıtlarında rastladığımız yegâne evrak, 1866 doğumlu Arif Efendi'nin babası olarak geçtiği "Filibeli Edhem Efendi" ifadesidir. Kendisinin bir kız ve bir erkek çocuğu vardır. Edhem Efendi, eşini genç yaşta kaybetmiştir; onun vefatından sonra da evlatlarına Hatîce Cenan Hanım bakmıştır. bk. BOA, DH.SAID., 58.23.

18 Araz, Anadolu Evliyâları, 449.

${ }^{19}$ Araz, Anadolu Evliyâları, 452.

${ }^{20}$ Ken'ân Rifâî, Sohbetler (İstanbul: Kubbealtı Neşriyâtı, 2000), 43, 217, 236, 249, 331, 395, 437, 489.

${ }^{21}$ Adana halkının mektep yaptırma konusunda oldukça istekli olduğu bilinmektedir. Bölgenin kaynaklarını bu yönde kullanmak hususunda bilinçlidirler. Bu amaçla vakıf kurmak, bazı akarların gelirlerini eğitime tahsis etmek çokça görülen faaliyetlerdendir. Dolayısıyla Maârif Müdürü'nün ve bölge idarecilerinin eğitim amaçlı olarak kaynak arayışlarında bölge halkının durumunu iyi değerlendirdikleri, ataerkil bir yaklaşımla meseleleri ele aldıkları söylenebilir. Adana halkının eğitime olan destekleri hakkında daha fazla bilgi için bk. Kâmil Şahin, "19. ve 20. Yüzyılda Adana İslam Sıbyan Mektepleri Üzerinde Gözlemler", II. Uluslararası Karacaoğlan - Çukurova Halk Kültürü Sempozyumu (Adana: Çukurova Üniversitesi Basımevi, 1993), 445-456. 
nasındaki vazifeleri dolayısıyla 31 Mart 1891 tarihinde rütbe-i sâlise tevcih olunmuştur. ${ }^{22}$

Ken'ân Rifâî, 2 Mart 1891 tarihinde Manastır Vilâyeti Maârif müdürlüğüne tayin edilmiştir. Mekteb-i idâdîde bir süre Mevâlid öğretmenliği de yapmıştır. ${ }^{23}$ Rifâî, bölgede görevliyken siyasi huzursuzlukların eğitim üzerindeki olumsuz etkilerini bertaraf etmeye çalışmış; bu amaçla Maârif Nezâreti'nin dönem anlayışı dışında hareket eden kesimlerle mücadele içinde olmuştur. O sırada etnik cemaatler, milliyetçilik akımının heyecanı içinde kendi kültürlerine hizmet edecek mektepler açmak yolunda resmî olduğu kadar gayri resmî yolları da mubah gören bir anlayış içerisindedir. Rifâî'nin, farklı milletlerin okul açma ve bu suretle bölgede nüfus kazanma girişimleri ile hükümetin bölge hakkında devamlı olarak değişen idarî kararları arasında hassas bir denge takip ettiği anlaşılmaktadır.

Ken'ân Rifâî, Manastır'da iken, mürşidi Edhem Efendi onun yanına gelmiş ve yakında bu dünyadan ayrılacağı haberini vermiştir. Bir yıl önce İstanbul'dan ayrılırken Hatîce Cenân Hanım'a da yakın zamanda vefat edeceği ve dolayısıyla bir daha dünya gözüyle görüşemeyeceklerini bildirmiştir. ${ }^{24}$ Rifâî, Manastır'dan ayrıldıktan üç ay sonra, mürşidinin vefat ettiği haberini almıştır. Edhem Efendi vefat ettiğinde kırk beş yaşındadır. Rehber-i Sâlikin adlı eserinde Rifâî, Edhem Efendi'nin vefatından sonra mânâda kendisine hilâfet vazifesi tevdî ettiğini kaydetmektedir. ${ }^{25}$ Bundan sonra mürşidiyle olan irtibatının, öncekinden daha kuvvetli bir şekilde, mânâ âleminden aldı̆̆ işaretlerle devam ettiği rivâyet edilmiştir.

Ken'ân Rifâî, becâyiş usûlü ile geçtiği Kosova Maarif Müdürlüğü vazifesine 12 Nisan 1893'de başlamıştır. ${ }^{26}$ Vekâleten ve asâleten Kosova Mekteb-i İdâdîsi'nde Fransızca dersi muallimliğinde bulunmuştur. Burada vazifeli bulunduğu dönemde bir maârif müdürünün yükümlülüğü içerisinde olan hemen bütün meseleler bizzat ilgilendiği arşiv kayıtlarından takip edilebilmektedir. Yeni okullar açmak, okullara öğretmen ve araç gereç temin etmek, bölge halkını yeni eğitim metodlarına ve maârife destek olmak konusunda bilgilendirmek ve ekalliyet mektepleriyle ilgilenmek bu meselelerin başında gelmektedir. II. Abdülhamid dönemi maârif islahatlarının uygulanmasıyla bizzat ilgilenen Rifâî, bu bölgede gerilimin arttığı bir dönemde Trabzon'a tayin edilir.

\footnotetext{
22 BOA, IDH., 1221.95580.

23 BOA, MF.MKT, 159.125.

24 Ayverdi vd., Ken'ân Rifầi ve Yirminci Yüzyılın Işı̆̆ııda Müslümanlık, 40.

25 Rifâî, Rehber-i Sâlikîn, 20-21.

26 BOA, MF.MKT., 173.110.
} 
Ken'ân Rifâî, 1896 tarihinde Trabzon Vilâyeti Maârif Müdürlügü̈ne nakledilir. İşe başladığı tarih itibariyle Hıfzu's-sıhha ve Fransızca muallimlikleri de uhdesine verilmiştir. Daha sonra Mâlûmat-ı fenniyye ve Coğrafya dersleri de ilave edilir. Rifâ̂̂, burada bir yıla yakın bir süre görev yaptıktan sonra aldığı mânevî bir işaret üzerine İstanbul'a döner ve burada 1897 tarihinde Numûne-i Terakki İdâdîsi müdüriyetine atanır. ${ }^{27}$ İstanbul'daki görevi sırasında yine mânâ âleminde aldığı bir işaret üzerine, Medine'de kurulma aşamasında olan Medine İdâdisi'ne tayinini ister.

Ken'ân Rifâî, 14 Şubat 1901 tarihinde Medine-i Münevvere Mekteb-i İdâdîsi'si müdürü olarak göreve başlar. Aynı anda birçok dersin de öğretmenliğini üstlenmiş durumdadır. ${ }^{28}$ Medine'ye geldiğinde Medine İdâdîsi kurulma aşamasındadır. Arşiv kayıtlarından anlaşıldığı üzere, henüz inşaat halinde olan ve aslında bir rüşdiye olması planlanan mektep, İstanbul'dan yeni bir müdürün geleceği yönündeki haberlerle birlikte idâdîye çevrilmiştir. ${ }^{29}$ Henüz mektep binası tamamlanmamış olduğundan dersleri Ravza-i Mutahhara'da yapmaya başlayan Rifâî, buradaki derslerden aldığ zevki, "Talebeyi toplayıp, Harem-i Şerif'te, Hazret-i Peygamber'in huzurunda bir ă̆ızdan salât u selâm getirmek, benim için en büyük dünya saadetlerinin üstünde idi." ${ }^{\prime 30}$ ifadeleriyle dile getirmektedir. Bu durum çok sürmez. Rifâî, kısa sürede inşa ve kurulumuna muvaffak olduğu mektep bünyesinde İstanbul okullarından getirdiği en yeni usullerle tedrisata başlar. Rifâî bir yandan mektep inşaatına hız verirken diğer yandan kısa zaman içerisinde okula bir çok öğrencinin kayıt yaptırmasına vesile olur. ${ }^{31}$

Ken'ân Rifâi için Medine dönemi, mânevî açıdan olgunluğa eriştiği bir zamandır. Rifâî, oradayken aldığı mânevî bir işaretle Medine şeyhü'lmeşâyihi olarak bilinen Hamza er-Rifâ̂̀'ye intisap eder ve üç yll boyunca onun tekkesine hizmet ederek, Rifâî usûlü ile seyr ü sülûkunu tamamlayıp icâzet alır. Rifâî́nin bu dönemde Hz. Peygamber'in (s.a.s) huzurunda geçirdiği murakabe zamanlarından ve Hamza er-Rifâ̂' nin tekkesinde yaptığı Rifâî sülûkundan oldukça feyz aldığı görülmektedir. Esasen Ravza-i Mutahhara'ya yakın olarak Peygamber şehrinde yaşamak ve orada hizmetli olmak, Rifâî'de başlı başına bir zevk ve vecd vesilesidir. Ravza-i Mutahhara'da yazdığı ve birçoğunu bestelediği ilâhî ve naatlar bu dönemin ne ölçüde verimli olduğunu göstermektedir. Rifâî, orada ka-

${ }^{27}$ BOA, DH.SAID., 72.405.

${ }^{28}$ BOA, DH.SAID., 72.405.

${ }^{29}$ BOA, I...MF., 6.58.

${ }^{30}$ Rifâî, Sohbetler, 500-501.

${ }^{31}$ Ayverdi vd., Ken'ân Rifâi ve Yirminci Yüzyılın Işı̆̆ııda Müslümanlık, 98. 
leme aldığı naatlarında bir maârifçi ve idareci kimliğinden öte bir Hakk âşığı olarak karşımıza çıkar. Allah ve Resûlü'nün aşkı onu her vesileyle Mescid-i Nebevî̀ye ve o kapıdan süzülerek geçtiği bir muhabbet âlemine çekmektedir. Bu vecd anlarında kaleme aldığı şiirlerinde, noksanını itiraf ederek Hakk'ın af ve merhametine Hz. Muhammed'in (s.a.s) ise şefaatine sığınır. Onun için hayattaki en büyük lütuf bu huzurunda bulunmaktır ve en büyük acı ise oradan ayrı kalmaktır: "Bir avuç toprak vücûdum girdi bahr-i lütfuna." ve "Hiç azad etmem kabul kurbânınım şâhım meded"32 misraları onun hislerini en veciz şekilde ortaya koymaktadır. Ayverdi, Hamza er-Rifâî’nin, Ken'ân Rifâî'ye icâzet verirken “Oğlum ben mi senin şeyhinim, sen mi benim şeyhimsin, onu bilemiyorum." ${ }^{\prime 33}$ dediğini kaydeder. Hamza erRifâ̂̀'nin bu sözleri, Ken'ân Rifâî'nin manevi olgunluğunun işareti olarak kabul edilmektedir. Bize göre Rifâî, üç yıl boyunca, aşk, fakr ve yokluk gibi tasavvufî makamların kemal derecelerini tecrübe etmiş görünmektedir.

Ken'ân Rifâî, 11 Mart 1905 tarihinde Dersaâdet Dârü̈l-muallimîn-i Âliye şubesi Fransizca muallimliğine ${ }^{34}$ ve Ocak 1906 'da teftiş ve muayene heyetine tayin edilir. ${ }^{35} 5$ Şubat 1908 tarihinde Maârif Nezareti Celîlesi Teftiş ve Muayene Heyeti âzâlığına ve sonrasında 1 Ekim 1908'de Dârü'ş-şafaka Mektebi müdürlügüne tayin edilir. ${ }^{36}$ Bir yıl sonra Fransızca öğretmenliği asaleten kendisine verilir; akabinde emekliye ayrılır.

Dârü'ş-şafaka Mektebi müdürlüğüne devam ederken, 1908 yılı içerisinde, Meclis-i Meşâyih'e bağlı bir Rifâi şeyhi olarak göreve başlar. Başbakanlık Osmanlı Arşivi'ndeki kayıtlardan anlaşıldığı üzere Ken'ân Rifâi, 1908 senesi itibariyle Rifai Tarikati Şeyhi/Rufâiyye meşâyihinden ${ }^{37}$ unvanıyla anılmaktadır. Rifâ̂i, Medine'den İstanbul'a dönüşünden yaklaşık dört yıl sonra Fatih semtinde Kırtay Sokak'ta kendi ikamet ettiği konağın avlusunda Ümmü Ken'ân Dergâhı'nı açar. Ümmü Ken'an Dergâhı, 23 Recep 1326/21 Ağustos 1908'de yapılan bir merasim ve âyinle açılmıştır. Tekke'nin vakfiyesi 1908 yılına aittir. Bazı kaynaklarda Altay Dergâhı olarak anıldığı görülse de resmî adı Ümmü Ken'ân Dergâhı'dır. Fatih'te Altay semtinde bulunması nedeniyle, "Altay'daki Rifâî Dergâhı" anlamında bu şekilde anıldığı ve zamanla kullanımın yaygınlaşmış olduğu anlaşılmaktadır. ${ }^{38}$

\footnotetext{
${ }^{32}$ Rifâî, Illâhiyât-ı Ken'an, İlâhî ve Manzûmeler (İstanbul: Cenan Eğitim, Kültür ve Sağlık Vakfı Yâyınları, 2013), 31.

${ }^{33}$ Ayverdi vd., Ken'ân Rifầ̂ ve Yirminci Yüzyılın Işı̆̆ında Müslümanlık, 100.

${ }^{34}$ BOA, DH.SAID., 72.405

${ }^{35}$ BOA, MF.MKT., 905.49.

${ }^{36}$ BOA, DH.SAID., 72.405.

${ }^{37}$ BOA, MF.MKT., 1067.13.

${ }^{38}$ Aydın Yüksel, "Ümmü Ken'ân Tekkesi”, Dünden Bugüne İstanbul Ansiklopedisi (İstanbul:
} 
Ken'ân Rifâ̂̂, bu tarihten itibaren Ümmü Ken'ân Dergâhı'nda Rifâî seyr ü sülûku üzere müridlerin terbiyesiyle ilgilenmeye başlamış, 1925 yılında tekke ve zaviyelerin ilgasına kadar bu görevine devam etmiştir. Haftanın belli günleri âyin ve takrirler için tahsis edilmiştir. ${ }^{39}$ Cuma namazından sonra Mesnevî takriri ve âyin-i şerif icra edilmektedir. Şeyh, Rifâi hemen her gününü belli dinî ve tasavvufî ritüellerin icrasına ayırmıştır. Farklı tariklerden icâzetli olduğu için Rifâî usûlünün yanı sıra bazı günler Kadirî ve Şâzelî usûlü zikir yaptığı da kaydedilmektedir. Zikir için tahsis edilen günlerin, annesi Hatîce Cenan Hanım tarafından belirlendiği ve diğer tekkelerin zikir geceleriyle aynı güne gelmemesine dikkat edildiği nakledilen bilgiler arasındadır ${ }^{40}$ Ken'ân Rifâî, dergâhını açmadan önce İstanbul'daki tekkeleri gezerek zikir usûlüyle ilgili mâlumatını geliştirdiğini kaydeder. Rifâî, bu ziyâretler sonunda elde edilen malumatın kâfi geldiği bir noktada hislerini şu ifadelerle beyan etmiştir:

“Ben tekkeden yetişmedim, dergâh açılacağı zaman ağabeyimle tekke tekke gezip usûl, erkân öğrenmeye çalışmıştık. Şeyhler meclisinde filân kimse beyyûmî zikri çok güzel yaptırıyor, falan kayyûmî zikirde daha ileri gibi hükümlerle, mürşitliği zikir ve devranda üstat olmakla ölçerlerdi. Halbuki tarikat demek, edep, irfan ve insanlık demektir." 41

Ken'ân Rifâî'nin konu ile ilgili açıklamalarından, tekke kurumu ve tekke şeyhliğinin zâhirî unsurlar üzerinden tanımlanması yahut bu unsurlara indirgenmiş olması durumundan bîzar olduğu anlaşılmaktadır. Buradan, geleneksel anlamda bir tekke tesisine niyetlenen Rifâî'nin, tekkelerin mevcut haline yönelik eleştirel bir yaklaşım içerisinde olduğu anlaşılmaktadır.

Şeyh Ken'ân Rifâî'nin dergâhı, dinî ve tasavvufî ritüellerin icra edildiği bir mekân olmakla birlikte, dönemi içerisinde önemli sosyal fonksiyonlar da yerine getirmiştir. Ümmü Ken'ân Dergâhı, müntesiplerini ve muhiblerini, mânevî değerler etrafında birleştiren ve bu alanda onları besleyen bir kültür merkezi haline gelmiş görünmektedir. Işın’a göre, “Tekke, Cumhuriyet döneminde de faaliyetine devam etmiş, aydın zümresinin ră̆bet ettiği bir merkez olma özelliğini taşımıştır. "42 Demirci, Rifâî'nin dergâhının geleneksel

Kültür Bakanlığı ve Tarih Vakfı Ortak Yayını, 1994), 6/111-112.

${ }^{9}$ Gürbüz Ertürk, “Ümmü Ken’ân Dergâhı”, Rahmet Kapısı: Uluslararası Kenan Rifâ̂ Sempozyumu (İstanbul: Nefes Yayınları, 2017), 153-159.

${ }^{40}$ Cemâlnur Sargut, Kenan Rifâ̂̀ ile Aşka Yolculuk, drl. Sadık Yalsızuçanlar (İstanbul: Nefes Yayınları, 2014), 179.

${ }^{41}$ Ayverdi vd.,Ken'ân Rifâî ve Yirminci Yüzyılın Işı̆̆̆nda Müslümanlık, 122.

42 Ekrem Işın, "Rifaîlik", Dünden Bugüne İstanbul Ansiklopedisi (İstanbul: Kültür Bakanlığ1 ve Tarih Vakf1 Ortak Yayını, 1994), 6/325-330. 
tekke kurumunun hemen bütün özelliklerini taşıdığını ve bu suretle dönemin kültür hayatına katkıda bulunan faydalı insanlar yetiştirdiğine dikkat çeker. ${ }^{43} \mathrm{Bu}$ ifâdelerden anlaşıldığ 1 üzere, Rifâ̂'’nin konağ 1 ve tekkesi, son dönem Osmanlı toplumunun bünyesi üzerinde savaş yıllarının meydana getirdiği ümitsizlik, yorgunluk gibi duyguların izâlesinde önemli bir moral merkezi olarak faaliyet göstermiştir:

“Mütareke yılları idi (1918 sonları) (...) Civarımızda tarik-i Rifâiyye'den Ümm-i Ken’ân dergâhında her Cuma namazdan sonra Rifâî âyîni icrâ edilirdi. $\mathrm{O}$ meş'um günlerin elem ve ıstıraplarını kısmen de olsa dindirebilmek için oraya giderdik (...) âyinden sonra dergâhın şeyhi Ken'ân Rifâî'nin odasına gidiliyor, ilmî ve edebi sohbetler ediliyordu." ${ }^{\prime 4}$

Şeyh Ken'an Rifâî'nin oğlu hafız mevlidhan Kazım Büyükaksoy, Ümmü Ken'ân Dergâhı'ndaki irşad faaliyetleri hakkında oldukça ayrıntılı bilgiler vermektedir. Buna göre, cuma günleri tertip edilen ayinde, semâhâne dervişlerle dolmaktadır. Reis Ahmet Efendi adlı bir zât onların ortasında bulunur ve Ken'ân Rifâî'nin verdiği işâretlere göre zikri idâre eder. Zikirde İstanbul'un kıymetli ve güzel sesli zâkirleri bulunmaktadır. Zâkirbaşı Yaşar Efendi'nin idâresi altındaki zâkirler, semâhânenin ortasında iki tarafa serilmiş bulunan postların üzerinde oturarak bizzat Rifâ̂̀'nin bestelediği ilâhîler ile klasik tekke musikisinde yer etmiş Arapça ve Türkçe çeşitli ilâhileri hep bir ağızdan okurlar. Böyle günlerde ihtiyaç sahibi dervişhâna ikram ve taltiflerde bulunulmaktadır. Her cuma günü, İstanbul'un muhtelif semtlerinden gelen farklı tarikatlara mensup on beşe yakın şeyhin mukabele esnasında hazır bulunduğu kaydedilmektedir. Ümmü Ken'ân Dergâhı'nda, ihyâ ya da başka bir deyişle kandil geceleri, ayin günlerinden biraz daha hareketli geçmektedir. Kandil gecelerinde gece yarısına kadar Kazım Bey'in ifadesiyle "müstesnâ" bir manevi toplantı yapılmaktadır. Bu gecelere özel ritüeller arasında burhan çıkarmak gibi Rifâî uygulamaları da vardır. Bazı zamanlar kandil haftalarında zâkir başı Yaşar Baba tarafından Mevlid-i Şerif okunmaktadır. Muharrem ayının 10. günü ihyâ edilen Aşûre gününde tarihi iki büyük kazanda tevhid ve mersiyeler eşliğinde âşure pişirilmesi adettendir.

Ken'ân Rifâ̂i'nin tekkesinde Ramazan ayının ihyâsı otuz gün boyunca sürmektedir. Terâvih namazı Şeyh Bedrettin Efendi ya da Medine'den Ken'ân Rifâî ile birlikte gelmiş olan Ömer Efendi tarafından kıldırılmaktadır. Yine Ramazan ayı boyunca pazartesi ve cuma geceleri dervişler, iftar-

${ }^{43}$ Demirci, “Ken'ân Rifâînin Mânevî Dünyâsı", 40.

${ }^{44}$ Mustafa Özdamar, Celâl Hoca (İstanbul: Marifet Yayınları, 1993), 34-35. 
dan sonra Şeyh Ken'ân Rifâi ile buluşarak bir saat kadar sohbet dinleme imkânı bulmaktadır. Kahve nakîbi Şakir dede adlı bir zat dervişlere ve misafirlere kahve hazırlamakla görevlidir. Ramazan ve Kurban bayramlarını takip eden cuma günlerine mahsus olarak ise gündüz saatleri içerisinde növbe, kudüm ve burhan merâsimleri yapmak tekkenin uygulamaları arasindadir. ${ }^{45}$

Yukarıdaki ifadelerden anlaşıldığı üzere Ken'ân Rifâînin dergâhı, tekke kurumundan beklenen hemen bütün fonksiyonları icrâ etmektedir. ${ }^{46}$ Ken'ân Rifâî, temelde Rifâî usulünü benimsemiş ve bu yönde eğitim vermiştir. Ancak, yerine göre icazetli olduğu Kadiri ve Şazeli usulünü de tatbik etmiştir. Sohbet notlarından anlaşıldığı üzere, konağı ve tekkesi devrin mühim tasavvuf büyüklerinin ve din adamlarının bir araya geldiği bir merkez durumundadır. Zaten İstanbul'da üç yüz kadar tekkenin bulunduğu Fatih semtinde yer alması bu durum için gereken şartları da hazırlamış görünmektedir.

Gerçekten, Rifâ̂' nin eserlerinden tasavvuf literatürüne son derece hâkim olduğ $\mathrm{u}^{47}$ ve bu yönüyle müridlerinin akıllarına ve gönüllerine aynı anda hitap ettiği anlaşılmaktadır. ${ }^{48}$ Sargut'a göre, Rifâî'nin Ümmü Ken'ân Dergâhı'nda aktardığı, ilim, aşk ve marifet ile asıl muradı kendisiyle ve çevresiyle barışık insan modeline ulaşmaktır. Bir anlamda samimi Müslüman yetiştirmektir. ${ }^{49}$ Ken'ân Rifâî tekkelerin kapatılması ile ilgili kararın ardından derhal Ümmü Ken'ân Dergâhı'ndaki eğitim faaliyetlerine son vermiştir. Şeyh Rifâ̂' nin bu dönemdeki tavrı, her şeyin Hakk'tan olduğu ve bu zuhuratta da bir hayır olduğu yönündedir. Rifâî, bu hususta yalnız değildir. Birçok tekke şeyhi benzer şekilde düşünmekte ve hareket etmektedir. Ancak onun ayırt edici tarafı, tekke ve zaviyelerin seddinden sonraki şu ifâdelerinden anlaşılır: "Tekkeler bir gün açılacaktır. Ancak akademi olarak açılacaktır." 50

Ken'ân Rifâî'nin Maârif Nezâreti'ndeki görevleri sırasındaki uygula-

${ }^{45}$ Prof. Dr. Emre Ömürlü, Ken'ân Rifâî’nin oğlu Hafız Mevlidhan Kâzım Büyükaksoy ile mülakatından.

${ }^{46}$ Tarihi süreç içerisinde tekkelerin ifa ettiği fonksiyonlar için bk. Mustafa Kara, Din-Hayat Sanat Açısından Tekkeler ve Zaviyeler (İstanbul: Dergâh Yayınları, 2013), 49-51.

${ }^{47}$ Rifâî'nin tasavvufi görüşleri için bk. Yalçınkaya, Ken'ân Rifầ'’nin Mesnevî Sohbetleri, 62-136.

${ }^{48}$ Demirci, Ken'ân Rifâî Yazlları, 25.

${ }^{49}$ Sargut, Kenan Rifâî ile Aşka Yolculuk, 218.

${ }^{50}$ Can Ceylan, Yirmi Birinci Yüzyıl Türkiye'sinde Tarikat Hayatı ve Tasavouf Anlayışı: Rifâî Şeyhi Ken'ân Rifâ̂'’nin Günümüzdeki Takipçilerinin Sanatsal, Kültürel ve Siyâsi Faaliyet ve Tavırlarn (İstanbul: Yeditepe Üniversitesi, Sosyal Bilimler Enstitüsü, Antropoloji Bölümü, Doktora Tezi, 2014), 85. 
maları incelendiğinde Osmanlı son dönem maârif müfredatına tasavvuf düşüncesini ve literatürünü entegre ettiği görülmektedir. Bunu gerçekleştirirken, yeni eğitim usûleri ile geleneksel uygulamaları, öğrencinin ihtiyacına göre terkip ederek bazı pratikler ortaya koyduğu görülmektedir. Zira Rifâî, tasavvufi değerlerin yaşayan bir örneği olmasının yanı sıra ders müfredatlarında dini ve tasavvufî metinleri kullanmak suretiyle tasavvuf düşüncesini son derece etkili bir şekilde örgün öğretime dahil etmiştir. Bu cümleden olmak üzere şu örnekler verilebilir: Fransızca dersinde Arapça hadisleri Fransızcaya çevirdiği görülmektedir. Ken’an Rifâi, bu tercümelerde dinin zahiri unsurlarından çok manevi ve ahlaki güzelliğini vurgulayan hadisleri seçmektedir. Farsça dersinde, öğretim amaçlı kullandığ1 metinlerin başında Mevlâna Celâleddin Rumi'nin Mesnevi'si gelmektedir. Sınavlarda öğrenciden Mesnevi beyitlerinin Farsça'dan Türkçeye çevirmelerini istemektedir. Seçtiği Mesnevi beyitlerinde ağırlıklı tema: İnsanın yeryüzünde bulunuş gayesi, Allah ve insan sevgisidir. Okulda öğrencinin piyano ile çalıp okuyabileceği rast makamında ilahiler bestelemektedir. Derslerini çeşitli enstrümanlarla ilahi çalarak desteklemektedir.

Ken'ân Rifâî, sosyal bilimler, dil ve ahlak alanında dersler verdiği gibi fen bilgisi, sanayi, zirâat, sağlık bilgisi gibi dersler de vermiş; bu derslerinde tabiat güzellikleri ve eşyâdaki Hakk tecellisine dikkat çekerek, pozitivizmin hâkim olduğu bir çağda geleneksel insan ve âlem anlayışına vurgu yapmıştır. Rifâî, teknik ilerlemelerin insanlığın gayesi olarak telakki edildiği bir dönemde tasavvufî geleneğin insan için teklif ettiği gâyeye dikkat çekmektedir. O gâye Ken'ân Rifâî'nin ifâdesiyle, "Kendini ve bu sûretle Rabbini bilmektir." Teknik alandaki ilerlemeler ise insanın, bu dünyadaki anlamını idrak etmesine vesile olduğu ölçü de kıymetli ve anlamlıdır.

Yukarıdaki izahlardan anlaşıldığı üzere, Şeyh Ken'an Rifâî, Osmanlı devletinin son dönemininde etkin olan geleneksel ve modern kurumlarda yetişmiş bir şahsiyettir. Bu eğitim süreci neticesinde Doğu inanç ve kültür dünyasına vakıf olduğu kadar, Batı düşünce ve dillerine de aşinalık kesbetmiştir. Aynı zamanda her iki kaynağın kendisine kazandırdığı birikimi, meslek tecrübesi ile de birleştirerek kendine has bir senteze ulaştığı anlaşılmaktadır. Rifâî, bu kurumlardan elde ettiği bu sentezi, Maârif Nezâreti ve tekke şeyhliğindeki uygulamalarına da yansıtmıştır. Bu uygulamalarıyla, geçiş dönemi Osmanlı toplumunun tecrübe ettiği sorunların çözümüne katkıda bulunmak istediği anlaşılmaktadır. Bir tekke şeyhi olmakla birlikte, o tarihten itibaren tekke kurumunun tasavvuf eğitimi için yeterli olmayacağını kanaatinde olan Rifâî, tasavvuf eğitiminin modern eğitim 
kurumlarında devam edeceğini öngörmektedir. Bu modern eğitim kurumu öncelikle akademi ve üniversitelerdir. Ancak Rifâî, orta öğretimde çalışan bir maarifçi olarak, vazifeli olduğu dönemde bu eğitimi rüşdiye ve idadi müfredatına entegre ettiği tasavvufî içerikle gerçekleştirmiş görünmektedir.

Ken'ân Rifâî, Cumhuriyet Türkiyesi döneminde emekliliğinden sonra çeşitli özel kurumlarda öğretmenlik görevine devam etmiştir. Bu dönemde mânevi sohbetlerini yalnızca aile çevresinde sürdürmüştür. Rifâî'nin tekkesi, sosyo-kültürel hayatımıza katkıda bulunan bir çok insanın yetişmesine vesile olmuştur. Eserleri ve uygulamalarıyla geçiş dönemi Osmanlı tasavvuf hayatına tesir eden Şeyh Ken'ân Rifâî, 1950 yılından vefat etmiştir. Türbesi İstanbul Merkez Efendi kabristanındadır.

\subsection{Ken'ân Rifâî'nin Eserleri}

\subsubsection{Muktezâ-yı Hayât (İstanbul, 1308/1908)}

Ken'ân Rifâî yayın hayatına 1891 yılında yayınlanan Muktezâa-yı Hayât adlı eseri ile başlamıştır. Eser, tabiat bilgisi ile ilgili olup ortaöğretim s1nıflarında kaynak eser olarak kullanılmak üzere kaleme alınmıştır. ${ }^{51}$ Eser, tabiat hadiselerinden ilâhi hikmetlere ulaşmak gayesiyle yazılmamıştır ancak burada geçen ifadelerden Rifâ̂' nin varlık, âlem, insan, ilim ve fen anlayışının ayrıntılarına ulaşmak mümkündür. Müellif kimi yerde, tabiatın olağan üstü güzelliklerine ve tabiattaki unsurların insanı hayrette bırakan taraflarına da dikkat çekmektedir.

\subsubsection{Kirk Derste Arapça (1317/1901)}

Ken'ân Rifâî, Kırk Derste Arapça adlı kitabı 1317/1901 tarihinde Medîne'de bulunduğu sırada kaleme almıştır. Bazı kaynaklarda Türklere Arapçayı konuşturan kitap ya da Türkler için Arapça başlıkları ile de geçmektedir. Kitap el yazması olarak büyük boy 84 varak ya da 168 sayfadır. Eserin hattı Ken'an Rifâî́ye âittir. Lafza-i celâl ve besmele ile başlayan eser, kırk bölümden oluşmaktadır.

\subsubsection{Rehber-i Sâlikîn (İstanbul 1327/1909)}

Rehber-i Sâlikinn, Ken'ân Rifâî'nin tarikat usûl ve âdâbını ele aldığı bir kitaptır. Eserde Ahmed er-Rifâî ve nesebi hakkında bilgilerden sonra sohbet, telkin, zikir, sülûktaki derecelerde müridlerin halleri, riyâzât ve halvet

51 Ken'ân Rifâi, Muktezâyı Hayat (İstanbul: Karabet Matbaası, 1308/1891), 1. 
gibi konulara yer verilmiştir. ${ }^{52}$ Bundan başka eserde vird ve salavatlar, tasavvuf büyüklerinin sözleri ve Ken'ân Rifâi tarafından yazılan manzumelere de yer verilmiştir. Rehber-i Sâlikîn, Ken'ân Rifâî'nin tasavvufî görüşlerini ve irşâd usûlünü tespit etmeye imkân vermesi bakımından önemlidir. Eser, Mustafa Tahralı'nın günümüz alfabesine aktarması ve takdim yazısı ile yakın tarihte ikinci defa basılmıştır..$^{53}$

\subsubsection{Tuhfe-i Ken’ân (1327/1910)}

Tuhfe-i Ken'ân, yaklaşık üç yüz kırk hadisin nazmen tercümesi ve şerhi olup ayrıca İmam Bûsirî'nin (öl. 695/1296[?]) Kaside-i Bürde'sinin nazmen tercümesini ihtiva etmektedir. Eserde ayrıca Ken'ân Rifâ̂' nin bazı ilâhilerine de yer verilmiştir. Eser Arapça ve Osmanlıca telif edilmiş olup 127 sayfadır. Tuhfe-i Ken'ân (1327/1911), Ken'ân Rifâînin, Ümmü Ken'ân Dergâhı'nda postnişin olduktan sonra yayınladığı bir eseridir. Müellif eserin ilk bölümünde Hazreti Peygamber'in yaklaşık üç yüz kırk kadar hadisinden çıkarılan manaları nazmen tercüme etmiş ikinci bölümünde ise Peygamber hakkında yazılmış Arapça bir şiir olan Kasîde-i Bürde'yi yine nazmen çevirmiştir. Eserin, yakın tarihte günümüz alfabesine çevrilerek ikinci baskısı yapılmıştır. ${ }^{54}$

\subsubsection{Seyyid Ahmed er-Rifâî (İstanbul 1340/1924)}

Ken'an Rifâî'nin Ebu'-alemeyn Seyyid Ahmed er-Rifâi adlı eseri ilk olarak 1340/1924 yılında basılmıştır. Yayınlandığı dönemde kendi konusunda o güne kadar yazılmış eserler arasında muhteva bakımından en geniş eser olarak kabul edilmektedir. ${ }^{55}$ Telif tercüme türünde bir kitap olan Seyyid Ahmed er-Rifâî kitabında, Ahmed er-Rifâî' nin biyografisi ile beraber tasavvufun temel meseleleri ve Rifâî tarikine göre seyrü sülûk ele alınmaktadır.

\subsection{6. İlâhiyât-1 Ken'ân (İstanbul, 1341/1925)}

İlâhiyât-ı Ken'ân, Ken'ân Rifâî'nin manzûme ve ilâhilerini bir araya toplayan bir eserdir. İlk baskısı 1925 yılında yapılan kitap Ken'an Rifâî́nin Rehber-i Sâlikin ve Tuhfe-i Ken'an adlı eserlerinde geçen ilâhilerle birlikte diğer şiirlerini ihtiva etmektedir. Manzûmelerin büyük çoğunluğu aruzla

${ }^{52}$ Rifâî, Rehber-i Sâlikîn, 50-92.

${ }^{53}$ Rifâî, Rehber-i Sâlikîn, 1-9.

${ }^{54}$ Ken'ân Rifâ̂̂, Tuhfe-i Ken'ân: Armağan, haz. Mustafa Tahralı (İstanbul: Cenân Eğitim, Kültür ve Sağlık Vakfı Neşriyâtı, 2019), 19.

${ }^{55}$ Ken'ân Rifâî, Ebu'l-alemeyn Seyyid Ahmed er-Rifâî, haz. Mustafa Tahralı (İstanbul: Cenân Eğitim, Kültür ve Sağlık Vakfı Neşriyâtı, 2015), 9. 
yazılmıştır. Eserin ikinci bölümünde, Ken'ân Rifâî ve diğer bestekârlar tarafından bestelenmiş ilâhiler yer almaktadır. 2013 tarihinde Yusuf Ömürlü tarafından yeninden düzenlenerek yayınlanmıştır. ${ }^{56}$ Şeyhe göre Mesnevî, manzûm bir Kur'an tefsîri, Niyâzî Mısrî Divânı ise Mesnevî́nin lübbü yani özüdür. Ken'ân Rifâî, bu ifâdelerden sonra "Biz de onun lübbünü Illâhiyât-ı Ken'ân'da yaptık" ${ }^{\prime \prime 7}$ diyerek eserin muhtevâsı hakkında bilgi vermektedir.

\subsubsection{Mesnevi Hatıraları (İstanbul, 1952)}

İlk baskısı 1952 yılında yapılan Mesnevî Hatıraları, Ken'ân Rifâi’nin 1908-1925 yılları arasında Ümmü Ken'an Dergâhı'nda gerçekleştirdiği Mesnevi takrirleri esnâsında oğlu Kazım Büyükaksoy tarafından tutulan notlardan yapılan bir derlemedir. Eser 1963 yılında bazı düzeltmelerle yeniden basılmıştır. Mesnevî Hatıraları 2013 yılında, önceki iki baskı karşılaştırılmak ve giriş kısmına bir takdim yazısı eklenmek suretiyle yeniden basılmıştır. Eserin Ken'ân Rifâi ile ilişkisini göstermek bakımından ismi "Ken'ân Rifầ'nin Mesnevi Hatıraları" olarak değiştirilmiş ve derlemede geçen Mesnevi hikâyeleri tespit edilerek konular hikâye başlıklarına göre düzenlenmiştir. ${ }^{58}$

\subsubsection{Sohbetler (İstanbul, 1991, 2000)}

Ken'ân Rifâi' nin sohbet notlarının derlenmesinden oluşan diğer bir eser de Sohbetler'dir. ${ }^{59}$ Sâmiha Ayverdi'nin yayına hazırladığı kitabın ilk baskısı 1991-1992 yıllarında iki cilt olarak Hülbe Yayınları'ndan çıkmıştır. İkinci baskısı 2000 yılında Kubbealtı Neşriyâtı'ndan çıan kitap büyük boy 600 sayfadır. Eserde ibâdet ve ahlak ile ilgili kavramlar başta olmak üzere tasavvufun hemen hemen bütün önemli meselelerine değinilmektedir. Eser, Ken'ân Rifâî́nin, Kur'ân ve sünnet kaynaklı bir tasavvuf anlayışına sahip olduğunu göstermesi bakımından kıymetlidir.

\subsection{9. Şerhli Mesnevî-i Şerif (İstanbul, 1973)}

Ken'ân Rifâî'nin Mesnevî takrirlerine ait notların derlenmesinden oluşan diğer bir kitap Şerhli Mesnevî-i Şerîf tir. ${ }^{60}$ Eser, Rifâî' nin Mesnevî takrir-

\footnotetext{
56 Ken'ân Rifâî, İlâhiyât-ı Ken'ân: Notalarıyla Bestelenmiş İlâhiler, haz. Yusuf Ömürlü (İstanbul: Cenân Eğitim ve Kültür Vakfı Neşriyâtı, 2013).

57 Rifâî, İlâhiyât-ı Ken'an, 14.

${ }^{58}$ Kazım Büyükaksoy, Ken'ân Rifầi'nin Mesnevi Hatıraları, haz. Arzu Eylül Yalçınkaya (İstanbul: Nefes Yayıncilik, 2013).

59 Ken'an Rifâî, Sohbetler (İstanbul: Kubbealtı Neşriyâtı, 2000).

${ }^{60}$ Ken'ân Rifâî, Şerhli Mesnevî̀-i Şerîff(İstanbul: Kubbealtı Neşriyatı, 2000), I.
} 
leri sırasında Ziya Cemal Büyükaksoy, Semiha Cemâl ve Sâmiha Ayverdi tarafından tutulan not defterlerinden, I. cilde ait olanların karşılaştırılması ve bir heyet tarafından tetkik edilmesi ile yayına hazırlanmıştır. Heyet içerisinde bulunan Nihad Sâmi Banarlı (öl. 1974) eseri günümüz Türkçesi'ne kazandırmıştır. Uzun yıllar tekkesinde Mesnevî takrirleri yapmış olan Ken'ân Rifâî, bu eser bağlamında Mevlevî tarikinin aşk ve muhabbet anlayışı ile Rifâiyye'nin fakr ve yokluk anlayışını mezcetmiş olduğu söylenebilir. Ken'ân Rifâî, Ümmü Ken'ân Dergâhında on yedi yıl boyunca Mesnevî takriri yapmış olup bu derslere ait not defterleri üzerinde çalışmalar bulunmaktadır. ${ }^{61}$

\section{KEN'ÂN RIFÂÎ'NIIN DİN VE TASAVVUF ANLAYIŞI}

\subsection{Ken'ân Rifâî'nin Din Anlayışı}

Ken'ân, Rifâî'ye göre şeriat demek âlemin nizâmını koruyan kanun demektir. Bu kanun küçük ve büyük âlem için geçerlidir. Şerîat esasları, insanın kemâle ermesi içindir. Şeriat hakikatin madde planındaki ifadesidir:

"Şeriat demek, âlemin nizâmını koruyan kânun demektir. Sâdece namaz, abdest ve oruç gibi ibâdet yol ve usûllerini tâyin eden bilgi demek değildir. Herhangi bir memlekette nizâm ve muvâzeneyi sağlayan kânunların hiçbiri şeriatın hâricinde olamaz. Meselâ şeriat hırsızlığı menediyor da kânun ve hukuk nizâmları menetmiyor mu? Yalanı, hileyi, hakareti şeriat istemiyor da kânunlar hoş mu görüyor? Onun için şerîat kalksa dünya da alt üst olur." ${ }^{\prime 2}$

Rifâî'ye göre, şeriat hakikatin madde planındaki formel ifadesi olsa da hakikatin ifadeye gelebilecek en muteber halidir. Yoksa hakikat bihakkın zâhir olsa şeriat ve nizam kalmaz. Şeyhe göre fert dinin kendisinden istediği şeyleri yerine getirip kendi içinde ruh beden akıl bütünlügünü temin ettiği takdirde hayırlı bir vücûda dönüşecektir. Bu noktada dinin, ferdi boyutu aşarak cemiyet nizamını muhafazaya yönelik fonksiyonları da görülmeye başlayacaktır. Zirâ Ken'ân Rifâî’ye göre, dinin temeli iman; hayatı ve devamı ameldir. İbâdetlerden sonra insanı kemale eriştiren en önemli amel ise cemiyet nizamını koruyan hayırlı işlere yönelmektir. Ona göre, hayatı ibadet ve topluma hayırlı işler etrafında örülü insan ve dolayısıyla dünya-ahiret saadetine çalışan insan modeli dinin en temel hedef ve gayesidir. ${ }^{63}$ Fert, dinin ameli kısmını hakkıyla yerine getirdiği takdirde ruh

\footnotetext{
${ }^{61}$ Yalçınkaya, Ken'an Rifầi'nin Mesnevi Sohbetleri, 36 vd.

62 Rifâî, Sohbetler, 103-104.

${ }^{63}$ Ayverdi vd., Ken'ân Rifầ̂ ve Yirminci Yüzyılın Işı̆̆̆ında Müslümanlık, 299.
} 
ve beden disiplinini sağlayacak ve böylelikle halk sevgisiyle dolu olarak cemiyete faydalı olacaktır. ${ }^{64} \mathrm{Bu}$ anlamda din, özelikle de dinin kaidelerini teşkil eden şeriat kısmı ferdin iç ahengini temin eden bir metot olduğu gibi, aynı zamanda toplumun nizâmını tesis eden en büyük âmillerden biri olmaktadır. Ken'ân Rifâî'ye göre dinin fert ve toplum içinde bir emniyet sübabı olmasının önündeki en büyük tehlike dinin zâhirinde kalmaktır. Dindarlık, Hakk'a değil fakat dine tapmak hâline indirgenirse bu taklit seviyesinde kalmış bir imanın göstergesi olur. Ancak bundan biraz öteye gidilir ve zahir hükümlerin manasına nüfüz edilirse din, fert üzerinde hakiki tesirini gösterecektir. Şeyhin ifâdeleriyle:

"Herkese dindar denebilir. Sonra ilimdar, sonra âyindâr, daha sonra da hakîkatdâr derler. Çünkü umumiyetle dindar ibâdet ve tâatla yâni taklitle tapıcıdır. Daha bir derece yükselince görmekle tapıcı olur. Bir derece daha yükselince hakîkatle tapıcı olur, ki asıl tapmak da budur. Hakîkat odur ki tapan ve tapilan bir ola." ${ }^{65}$

Rifâîye göre dinin zâhiri unsurlarını tatbik etmekle birlikte, bunları din mevkiine koymak hatasına düşülmemelidir. Küçük, Ken'ân Rifâi'nin sûretperestliğe karşı duran bu yaklaşımının Mevlânâ'nın Mesnevi'de ortaya koyduğu tutumla benzerlikler arzettiğini kaydetmektedir. ${ }^{66}$ Rifâ̂̀'nin bu tavrını dönemi içinde değerlendiren Küçük, tarihi süreç içerisinde dini yorumların kutsal bir hüviyete büründüğüne ve hatta maddi unsurların dahi kutsal olarak kabul edildiğine dikkat çeker. Özellikle tasavvufun bu açıdan çokça eleştirildiği bir dönemde, Ken'ân Rifâî'nin tarihi süreçte dine karışan kabulleri dinin aslından ayırma çabasına dikkat çekmektedir. Rifâî'nin tekkeler kapandığındaki tavrı, yeni olanla barışıklığı, tasavvufi hayatın vazgeçilmezlerinden addedilen hirka, post vb. unsurların terkinde gösterdiği tutarlılık ve bu husustaki örnekliği nedeniyle Rifâî'nin kendi döneminde bir tür ihyâ ve tecdid faaliyeti içerisinde bulunduğunu kaydetmektedir. ${ }^{67}$

Ken'ân Rifâî'nin anlayışında öne çıkan bir başka husus ise dini katmanlarıyla birlikte değerlendirmesidir. Tasavvuf literatüründe bu katmanlar şeriat, tarikat, hakikat ve mârifet olarak ifade edilir. Şeyhe göre de dinin başlangıcı şeriat; nihâyeti hakikat mertebesine ermektir. Dinin zâhiri hükümleri yani şeriât, hakikâte giden yolun başlangıcıdır nihayeti ise ge-

\footnotetext{
${ }^{64}$ Ayverdi vd., Ken'ân Rifâî ve Yirminci Yüzyılın Işı̆̆ı̆nda Müslümanlık, 178.

${ }^{65}$ Rifâî, Sohbetler, 465.

${ }^{66}$ Osman Nuri Küçük, "Kenan Rifâî'nin Şerîat ve Din Anlayışı", Rahmet Kapısı Uluslararası Ken'an Rifâî Sempozyumu (İstanbul: Nefes Yayınları), 45-67.

67 Küçük, "Kenan Rifâî' nin Şerîat ve Din Anlayışı", 54-55.
} 
rek ibadeti gerek kulluğu her an Allah'ı görürcesine bir şuûr ile ifâ etmektir. "Dînin istediği sâdece namaz kılmak, oruç tutmak, sabahlara kadar oturup ibâdet etmek, hayrat ve hasenatta bulunmak değildir." ${ }^{\prime 68}$ diyen şeyh için bütün bu ibâdetlerin gayesi Hakk'ın rızasıdır.

Yukarıdaki ifadelerden anlaşılacağı üzere Ken'ân Rifâî, sufi gelenekte yer bulduğu şekliye şeriât, tarikat ve hakikat şeklinde derecelendirilen din anlayışını benimsemektedir. Bu yaklaşımın esas kaynağı ise Cibril hadisinde ortaya konan İslam, iman ve ihsân şeklindeki kademeli din anlayışıdır. ${ }^{69}$ Söz konusu derecelendirmenin, Rifâî' nin hemen bütün dini tasavvufi meseleleri ele alırken kullandığı bir yöntem olduğu görülmektedir. Şeriat ehlinin imanı ile tarikat ehlinin imanı arasında şuhûd açısından derece farkı olduğu gibi; ${ }^{70}$ ibâdetleri ifa etmek bakımından da aralarında farklar bulunmaktadır. İnsanların arasında, dini meseleleri idrak ve bunları yaşama bakımından çeşitlilik vardır. Rifâî bu çeşitliliği ifade etmek üzere yine sufi gelenekte öne çıkan bir tasnifle, yani avam, havas, havassu'-havâs tabirlerini kullanmaktadır. Dinî-tasavvufî meselelerin idrak ve ifâsında, avâm en temel esasları yerine getirmekte zorluk çekerken, seçkinleri ifade eden havas ve havassu'l-havas ise ilgili meselelerin derinliklerine nüfus etmek ve bunun gereğiyle amel etmek gücüne sahiptir. ${ }^{71}$ Ken'ân Rifâî, dinin iman, İslâm ve ihsân boyutlarına dikkat çekmekle birlikte, hakikat seviyesinde bir din idrakinin ancak ihsân derecesine ulaşmakla yaşanacağ 1 kanaatindedir.

\subsection{Ken'ân Rifâî'nin Tasavvuf Anlayışı}

Ken'ân Rifâî'nin Cibril hadisine istinaden dini iman, İslâm ve ihsân olarak üç katmanlı bir şekilde değerlendirdiğini ve ihsân derecesini ise tahkik seviyesinde bir din idraki olarak kabul ettiğini yukarıda belirttik. Gerçekten de Rifâî’nin eserlerine bakıldığında, ihsân kelimesinin Cibril

${ }^{68}$ Rifâî, Sohbetler, 222-223.

${ }^{69}$ Ebû Nasr Abdullah b. Alî b. Muhammed es-Serrâc et-Tûsî, el-Lüma':İslâm Tasavoufu, Tasavvufla İlgili Sorular ve Cevaplar, çev. Hasan Kamil Yılmaz (İstanbul: Altınoluk Yayınları, 1996), 10; Rifâî, Sohbetler, 548-549.

${ }^{70}$ Rifâî, Sohbetler, 190.

${ }^{71}$ Söz gelimi şükür konusunu tanımlarken bu derecelendirmeyi şöyle izah eder: "Şükür üç kısım olduğu gibi, aynı zamanda üç derecedir. Birinci derece, senin için makbul olan, hoşuna giden şeylere şükretmektir. Bu şükürde avam da havas da dâhildir. Meselâ evlât sahibi olmak, işi ilerlemek, maaşı artmak gibi, hoşlanılan hâdiselere şükretmektir. İkincisi, sevdiğin ve sevmediğin şeyleri bir tutarak, Hak'tan her ne gelirse ona razı olmaktır. Ama bu her kişinin kârı değildir. Üçüncüsü ise, nimeti veren Allah Zülcelâl'de o kadar müstağrak olmak ki, nimeti görmeye bile vakti olmamaktır, ki şükrün asıl mânâsı budur. İşte, bu şükür sahibinin önünde, bende ol, yok ol." Rifâî, Sohbetler, 316. 
hadisinde geçen "Allah'ı görürcesine ibâdet etme" anlamına vurgu yaptığı görülmektedir. Rifâî'ye göre tasavvuf, ihsân alanında çalışan bir ilimdir ve ahlâk dönüşümü neticesinde salikin Allah'ı görürcesine ibâdet ve kulluk etmesi tasavvufun gâyesidir.

Rifâî'nin her yerde Hakk'1 görürcesine ibadet etme konusuna son derece önem verdiği görülmektedir. Kul ibadet ederken de, çarşıda gezerken de her iş ve halinde, Allah'ın kendisini gözetlediğini bilerek bu idrak ile hareket etmelidir. Öyle ki salik, bu idraki sanki o da Hakk'ı her an görüyormuş̧̧asına devam ettirmelidir. Rifâi' nin bu anlayışı, Cibril hadisinde geçen ihsân tabirini hatırlatmaktadır. Bilineceği üzere sûfi müelliflerden Ebû Nasr es-Serrac (öl. 378/988), Tasavvuf-fıkıh ilişkisini izah ederken Peygamber'in (s.a.s) "İhsân, Allah'ı görüyormuş̧̧asına kulluk etmendir. Her ne kadar sen onu görmüyorsan da o seni görüyor." "72 ifadesindeki ihsânı, tasavvuf ilminin gayesi olarak tespit etmektedir. Serrâc, tasavvuf ilmi için bir alan arayışına yönelerek, hakikatler alanını tespit etmektedir. Ken'ân Rifâi' nin bu mealdeki açıklamaları, Serrâc'ın tasavvuf ilmini ihsân ile özdeşleştiren ifadelerine anlam açısından yakın görünmektedir. Buna göre Ken'ân Rifâî için tasavvuf ihsâna ulaşmanın yollarını öğreten bir ilimdir. Daha açık bir anlatımla tasavvuf Allah'ı görürcesine ibâdet etme ve O'nun tarafından müşâhede edildiğini bilerek yaşama yollarını öğreten bir ilimdir. ${ }^{73}$

Rifâî'nin bu görüş halinin, salikte hasıl ettiği ahlâk ve tavırlar üzerinden tasavvuf tarifi yaptığ da görülür. Şeyhin metinlerinde geçen bu mealdeki ifadeleri şöyle özetleyebiliriz: Tasavvuf ehli fenâ makamından geçerek bekaya ulaşmış, kendi nefislerinden ölerek Hakk'ın ebedi hayatı ile dirilmiş olanlardır. ${ }^{74}$ Onlar kendi özelliklerini bırakıp Hakk'ın sıfatlaryyla sıfatlanmış, isimlerini hakkıyla bilmiş ve bu suretle Allah'ın ahlakıyla ahlaklanmış olanlardır. Tasavvuf ehli kalplerini her türlü kötülükten temizledikleri için Allah'ın cemâlini seyretmek derecesine ermiş olanlardır. ${ }^{75}$ Allah tecellisini seyrettikleri için zâhir ve bâtın edebe riâyet ederler. Bu

${ }^{72}$ Bilineceği üzere Cibrîl hadisinde, Hz. Peygamber (a.s) İslam, iman ve ihsân kelimelerinin anlamlarını açıklar. Serrâc, bu hadisi İslâmî ilimlerin kendisinden neşet ettiği ya da üzerine binâ edildiği bir zemin olarak görmektedir. Buna göre meşhur Cibrîl hadisinde Hz. Peygamber'a (a.s) İslâm, imân ve ihsânın hakikatini soran vahiy meleğinin her bir sorusu için aldığı cevap ayrı bir ilim dalının mevzûsu olarak kabul edilmiştir. İlk iki soru Fıkıh ve Kelâm ilimlerine kaynaklık teşkil ederken, Allah'ı görürcesine ona ibâdet ve kulluk etme anlamındaki ihsân da tasavvuf ilminin doğuşuna kaynaklık etmiştir. Bkz. es-Serrâc, elLüma', çev. Hasan Kamil Yılmaz, 10.

${ }^{73}$ Rifâî, Sohbetler, 10.

${ }^{74}$ Rifâî, Sohbetler, 205.

${ }^{75}$ Rifâî, Sohbetler, 324. 
bakış, onları her an Allah'ın istediği şekilde hareket etme yönünde tedip eder:

“Tasavvuf güzel ahlâktır. İç ve dış edebiyle edeplenmektir. Dış edebi, yâni zahir edep, Allah'ın emrine uymak, nehyinden kaçmaktır. İç yâni bâtın edebi ise, hayvan sıfatlarından kurtulup iyi huylar ile alışkanlık peyda etmek, elinden, dilinden bir kimseyi kırmamak, rahatını bozmamak ve lüzumsuz düşüncelerden vesveselerden gönlünü pâk edip, Hakkın cemâli içinde gark olmaktır."76

Rifâî'ye göre tasavvufi metot, öncelikle riyâzat ve mücâhededir. Bu iki vasıta ile nefsin ıslahı ve kalp tasfiyesi gerçekleşir. Kalp tasfiyesini hasıl eden kişi her yerde ve her şeyde Allah'ın tecellilerini görmek derecesine erişir. O halde, tasavvufî metodun gayesi, riyazat ve mücahede ile bu görüşü temin etmektir. Tasavvufun gâyesi bir başka deyişle, taklid derecesindeki bir tevhid anlayışını, tahkik derecesinde bir tevhid anlayışına eriştirmektir. Rifâî́nin aşağıdaki ifadeleri bu açıdan önemlidir:

“Bu âlemdeki birlikten söz ediliyordu: O kimse ki kelime-i tevhidin mânâsını hal eder, yaşar ve ona göre hareket eder, Allah'tan başka fail, Allah'tan başka mevcut yoktur demek suretiyle failin ve mevcûdun Hak olduğunu bilirse, can, canan olmuş olur. O kimse, her mevcudun Cenâb-1 Hakk'a bir mâzhar olduğunu görürse ondan Hâk görünür. İşte ilim ve irfan budur. İrfan sahibi, marifet sahibi dediğimiz bu kimselerdir. O zaman, âlem içinde ona hayret ve ibretten başka bir şey kalmaz. Çünkü kaç kıyamet görmüş, herkes gibi bir adam iken ne büyük tasarrufa sahip ne azîm bir varlığa mâlik olmuş ve fena mertebesinden beka mertebesine geçmiştir. Hâsılı, bu dünyâda Hakk'tan gayrı nesne yoktur. (...) İnsan kendini bilir, fiil, kavi ve tasarrufun Hakk'tan olduğunu idrak edecek olursa, işte o vakit Allah'ını bilmiş olur. Yâni kendi yokluğunu bilen, Allah'ın varlığını bilmiş olur. Yok eğer bilmeyecek olursa, bu cehliyle nefsine zulmetmiş olur." 77

Yukarıdaki ifadelerden anlaşıldı̆̆ı üzere, tasavvufî metot insana bir görüş kazandırmak ister. İnsan, mutlak varlıktan bir nefs olarak ayrışıp kendi benliğini bildiği andan itibaren, hadiselere, eşyaya kendi nefsiyle olan müspet ya da menfi irtibatı açısından bakmakta ve bir anlam yüklemektedir. Bu bakış ve anlayış, salikte önce irade ve fiile sonrasında yaşam tarzı ve alışkanlıklara dönüşür. Ancak hakikate talip olan kişi, kendi nefsinin arzu, görüş ve iradesini bir kenara koyarak; her bir irade ve hareketinde Allah'ın istediği şeyi öne almaya başlayınca, tedricen kendi cüzi varlı-

\footnotetext{
${ }^{76}$ Rifâî, Sohbetler, 579.

77 Rifâî, Sohbetler, 320-324.
} 
ğını bırakarak Allah'ın ahlâk ve sıfatlarıyla sıfatlanmaya başlar. Mücâhede ve riyâzet ile yapılan tezkiye/temizlenme, nefsin üstündeki katmanları sökmek ve derinlerdeki aslî tabiatla buluşmak içindir. Gerçekten de Rifâî, ahlâk dönüşümünde, yani seyrü sülûkta mücâhede ve riyâzatı en önemli amil olarak görmektedir. Nitekim kendi varlığından fani olduğu nisbette Hakk'ın varlığı ile baki olur. Bu noktada artık sâlik eşyâyı, âlemi ve kendi nefsini dahi, kendi görüşüyle değerlendirmez ve Hakk'ın görüşüyle değerlendirmeye, âleme Hakk'ın nazarıyla nazar etmeye, eşyayı Hak'la kaim görmeye başlar. ${ }^{78}$ Ken'ân Rifâîye göre tasavvuf, kişiye bu görüşü, yani her şeyi "bir görme" yetisini kazandırmayı gaye edinmiş ilimdir.

\section{SONUÇ}

Ken'ân Rifâî, Osmanlı Devleti'nin sonu ile Cumhuriyet'in ilk yıllarında yaşamış Rifâî şeyhlerindendir. Filibe hanedanına mensup olan Rifâî, 1876 Bulgar isyanının akabinde, ailesi ile birlikte İstanbul'a taşınmıştır. Rifâî, dönemin modern eğitim kurumlarından Galatasaray Mektebi Sultânisi'nden mezun olduktan sonra Maârif Nezâreti bünyesinde çeşitli vilâyetlerde öğretmenlik, müfettişlik ve maârif müdürlügü yapmıştır. Şeyh Rifâi ilk mânevi terbiyesini annesi Hatice Cenân hanımdan almıştır. Formel manada ilk tasavvuf eğitimini ise Üveysi-Kadiri meşreb bir zat olan Filibeli Ethem Efendi'den almış olup Balıkesir memuriyeti sırasında bu zatın gözetiminde Kadiri usûlü ile seyrü sülûkunu tamamlamıştır. Medine'de bulunduğu sırada, şeyhül'l-meşâyıh Hamza Rifâî'nin tekkesine hizmet eden Rifâî, bu zattan Rifâî icâzetnâmesi almıştır. Ken'ân Rifâî, Fatih'teki konağının bahçesinde inşa ettirdiği Ümmü Ken'ân Dergâhı'da, Meclis-i Meşayıha bağlı bir Rifâî şeyhi olarak 1908 yılından tekkelerin ilga edildiği 1925 tarihine kadar irşad hizmetinde bulunmuştur. Rifâî, Doğu ve Batı düşünce dünyasını sentezleyebilecek şekilde dönemin geleneksel ve modern kurumlarında yetişmiş tipik bir son dönem Osmanlı mütefekkiridir. Bu kurumlardan aldığı donanımı tecrübeleri ile birleştirerek, içinde yaşadığı dönemin toplumsal meselelerine çözüm önerilerinde bulunmuştur. Bu cümleden olmak üzere, tasavvuf literatürünü modern eğitim müfredatına tatbik etmiştir. Böylelikle tasavvuf eğitiminin yeni dönemde maârif çatısı altında devamına işaret etmiş ve bunu temin etmek yolunda derslerinde tasavvuf literatüründen eserlere yer vermiştir. Eserleri ve besteleriyle, tasavvuf yazını ve musikisine katkılarda bulunan Rifâî, 1950 y1lında vefat etmiş olup İstanbul Merkez Efendi Kabristanı'nda medfûndur.

78 es-Serrâc, el-Lüma', çev. Hasan Kamil Yılmaz, 32. 
Ken'ân Rifâi, Ümmü Ken'ân Dergâhı'nda başta Rifâî usulü olmak üzere, icazetli bulunduğu Şazeli ve Kadiri usulü ile de seyrü sülük yaptırmıştır. Rifâ̂'’nin dergâhı, tekke kurumundan beklenen hemen bütün fonksiyonları icrâ etmektedir. Dergâhı başta semt sakinleri olmak üzere, İstanbul'dan ve geniş Osmanlı coğrafyasından pek çok kimsenin ziyaret ettiği manevi bir merkezdir. Ayrıca Meclis-i Meşayıh Arşivi'nden anlaşıldığı üzere, Ümmü Ken'ân Dergâh'1, son dönem Osmanlı toplumunda önemli bir moral merkezi olarak da görev yapmışır. 1925 yılında tekkelerin ilgası ile ilgili kararın ardından, tekke faaliyetlerini nihayete erdiren Rifâî, yeni dönemde tasavvufi eğitimin örgün eğitim kurumlarında devam etmesi gerektiği kanaatindedir. Rifâî Ken’ân Rifâî, son dönem Osmanlı toplumunda yetişmiş bir münevverdir. Doğu ve Batı kültür dillerine hakim olması ve bu kültürlere ait eserleri asıl kaynaklarından okuyabilmesi onun en önemli özelliğidir. Rifâ̂̂, XIX. yüzyıl Osmanlı düşünce hayatında birçok istihalelerin yaşandığı bir dönemde, maârif vazifeleri ve tekke şeyhliği vasıtasıyla tasavvufi hayatı canlı tutmak için gayret etmiştir. Bu özellikleri ile, İslam geleneğinden emin bir mutasavvif portresi arz etmektedir.

Ken'ân Rifâ̂̀'nin bütün sûfilerde olduğu gibi kademeli bir din anlayişına sahip olduğu görülmektedir. Dinin zâhiri kuralları olan şeriata riâyet, onun için din ve dünya hayatının muhafazası açısından elzemdir. Ancak kul, bu seviyede kalmayarak, dini hakikat seviyesinde yaşamaya gayret etmelidir. Tahkik derecesinde bir din idraki ise ona göre ancak ihsana ulaşmakla mümkündür. Rifâ̂̀'nin söz konusu kademelendirmeyi yaparken, Cibrîl hadisinde geçen, İslam, iman ve ihsân kavramlarını dikkate aldığı anlaşılmaktadır. Dinin hakiki anlamda yaşanması ise ancak ihsân ile bir başka deyişle tasavvufi yaşantı ile mümkündür. Ken'an Rifâî için din herkesin idrak ve gücü ölçüsünde gerçekleştirebileceği çeşitli katmanlardan oluşan bir yapıdır. İnanç ve ibadetle ilgili meseleler bu yolun başı olurken; Allah'1 görürcesine ibadet ve kulluk etmek, yani ihsan derecesi, bu yolun nihâyetidir.

Geçekten de Ken'ân Rifâî'nin, her yerde Hakk'ın tecellisini müşahede etme ve her an Allah tarafından murakabe edildiğini bilerek amel etme konusuna son derece önem verdiği görülmektedir. Ona göre kul gerek ibadethanede gerekse ticarethânede, her iş ve halinde, Allah'ın kendisini gözetlediğini bilerek hareket etmelidir. Sâlik, idrakinde bir derece daha ileri geçerek, Hakk'ı her an görüyormuşçasına yaşama gayretine devam etmelidir. Nitekim insan kendi varlığından fani olduğu nispette, Hakk'ın varlığı ile baki olmaktadır. Bu noktada artık sâlik aleme ve eşyaya, Hakk'ın 
nazarıyla nazar kılmaya ve eşyayı Hak'la kaim görmeye başlayacaktır. İşte tasavvuf, kişiye bu görüşü kazandırmayı, yani her şeyi "tevhid nazarıyla görme" yetisini kazandırmayı hedefleyen bir ilimdir. Rifâî'nin bu anlayışı, Hz. Peygamber'in Cibril hadisinde "İhsân, Allah'ı görüyormuş̧̧asına kulluk etmendir" şeklindeki ifâdesinin bir değerlendirmesi mahiyetindedir. Rifâî'nin yukarıda açıkladığımız ifadeleri, ilk dönem sûfi müelliflerinden Serrâc' in tasavvuf ilmini ihsan ile özdeşleştiren ifadeleriyle örtüşmektedir. Buna göre Ken'ân Rifâi için tasavvuf, ihsana ulaşmanın yollarını öğreten bir ilimdir. Daha açık bir anlatımla tasavvuf, Allah'ı görürcesine ibâdet etme ve O'nun tarafından müşâhede edildiğini bilerek yaşama yollarını öğretmektedir. Salik, bahsi geçen kemal derecesine erinceye kadar, birçok hal ve makamdan geçmek durumunda olduğu için, tasavvuf ihsan derecesine ulaştıran hal ve makamların ilmi olmaktadır. Bu izahlardan Rifâînin tasavvuf anlayışını, büyük ölçüde ihsân kavramı üzerine şekillendirdiği anlaşılmaktadır. 


\section{KAYNAKÇA}

Araz, Nezihe. Anadolu Evliyaları. İstanbul: Atlas Kitabevi, 1988.

Ayverdi, Sâmiha vd. Ken'an Rifâ̂̀ ve Yirminci Asrın Işı̆̆̆ında Müslümanlık. İstanbul: Kubbealtı Neşriyâtı, 2003.

Ayverdi, Sâmiha. Dost. İstanbul: Kubbealtı Neşriyâtı, 2017.

Binark, İsmet. Dost Kapısı: Ezel ve Ebed Arasında Ke'nan (Rifâî) Büyükaksoy. İstanbul: Cenan Eğitim, Kültür ve Sağlık Vakfı Neşriyâtı, 2005.

Büyükaksoy, Kazım. Ken'ân Rifâî'nin Mesnevi Hatıraları. haz. Arzu Eylül Yalçınkaya. İstanbul: Nefes Yayıncilık, 2013.

Ceylan, Can. Yirmi Birinci Yüzyıl Türkiyesi'nde Tarikat Hayatı ve Tasavouf Anlayışı: Rifâî Şeyhi Ken'ân Rifầi'nin Günümüzdeki Takipçilerinin Sanatsal, Kültürel ve Siyâsi Faaliyet ve Tavırları. İstanbul: Yeditepe Üniveritesi, Sosyal Bilimler Enstitüsü,Doktora Tezi, 2014.

Demirci, Mehmet.Ken'an Rifâî Yazıları. İstanbul: Cenan Eğitim, Kültür ve Sağlık Vakfı Neşriyâtı, 2016.

Demirci, Mehmet. "Ken'ân Rifâî’nin Mânevî Dünyâsı". Bir Yirminci Yüzyıl Münevveri Ken'ân Rifầ Sempozyumu Bildiri Kitabı. ed. Fulya Bayraktar. 61-68. İstanbul: Cenan Eğitim Kültür ve Sağlık Vakfı Neşriyâtı, 2015.

Demirdaş, Öncel. “Riyazet Eğitimi ile Gerçekleşen Manevî Olgunluk”. Dinbilimleri Akademik Araştırma Dergisi 11/1 (2011), 79-90.

Doğan, İsmail. “Eğitimci Ali Suâvi (1839-1878) ve Galatasaray Lisesi'ndeki Uygulamaları". Tanzimat'ın 150. Yıldönümü Uluslararası Sempozyumu. 515-538.Ankara: Türk Tarih Kurumu, 1994.

Ertürk, Gürbüz. “Ümmü Ken’an Dergâhı”. Rahmet Kapısı: Uluslararası Kenan Rifâ̂ิ Sempozyumu. 153-159. İstanbul: Nefes Yayınları, 2017.

Fortna, Benjamin C. Mekteb-i Hümâyûn, Osmanlı Imparatorluğu'nun Son Döneminde İslâm, Devlet ve Ĕ̆itim. çev. Pelin Siral. İstanbul: İletişim Yayınları, 2005.

Işın, Ekrem. "Rifaîlik". Dünden Bugüne İstanbul Ansiklopedisi. 6/325-330. İstanbul: Kültür Bakanlığı ve Tarih Vakfı Ortak Yayını, 1994.

İgüs, Esmâ. II. Abdühamid Dönemi Eğitim Sistemi, Eğitim Yapıları ve Askeri Rüşdiyeler. İstanbul: Yıldız Teknik Üniversitesi, Sosyal Bilimler Enstitüsü, Doktora Tezi, 2008.

Kara, Mustafa. Din-Hayat Sanat Açısından Tekkeler ve Zaviyeler. İstanbul: Dergâh Yayınları, 2013.

Kodoman, Bayram. Abdülhamid Devri Eğitim Sistemi. Ankara: Türk Tarih Kurumu Basımevi, 1988.

Küçük, Osman Nuri. “Kenan Rifâî’nin Şerîat ve Din Anlayışı". Rahmet Kapısı Uluslararası Ken'an Rifâi Sempozyumu. 45-67. İstanbul: Nefes Yayınları, 2017.

Özdamar, Mustafa. Celâl Hoca. İstanbul: Marifet Yayınları, 1993.

Rifâi, Ken'ân. Muktezâyı Hayat. İstanbul: Karabet Matbaası, 1308/1891. 
Rifâî, Ken'an. Sohbetler. İstanbul: Kubbealtı Neşriyâtı, 2000.

Rifâî, Ken'ân. Şerhli Mesnevî̀-i Şerîf. İstanbul: Kubbealtı Neşriyatı, 2000.

Rifâî, Ken'ân. İlâhiyât-ı Ken'ân: İlâhı̂ ve Manzûmeler. haz. Mustafa Tahralı. İstanbul: Cenan Eğitim, Kültür ve Sağlık Vakfı Neşriyâtı, 2013.

Rifâ̂̂, Ken'ân. İlâhiyât-ı Ken'ân: Notalarıla Bestelenmiş İlâhiler. Haz. Yusuf Ömürlü. İstanbul: Cenân Eğitim ve Kültür Vakfı Neşriyâtı, 2013.

Rifâî, Ken'ân. Ebu'-alemeyn Seyyid Ahmed er-Rifâî. Haz. Mustafa Tahralı. İstanbul: Cenân Eğitim, Kültür ve Sağlık Vakfı Neşriyâtı, 2015.

Rifâî, Ken'ân. Rehber-i Sâlikîn, Sâliklerin Rehberi. Haz. Mustafa Tahralı. İstanbul: Cenan Eğitim, Kültür ve Sağlık Vakfı Neşriyâtı, 2018.

Rifâî, Ken'ân. Tuhfe-i Ken'ân: Armağan. haz. Mustafa Tahralı. İstanbul: Cenân Eğitim, Kültür ve Sağlık Vakfı Neşriyâtı, 2019.

Sargut, Cemâlnur. Kenan Rifâî ile Aşka Yolculuk. Drl. Sadık Yalsızuçanlar. İstanbul: Nefes Yayınları, 2014.

Serrâc, Ebû Nasr Abdullah b. Alî b. Muhammedet-Tûsî. el-Lüma' İslâm Tasavvufu, Tasavvufla İlgili Sorular ve Cevaplar, Çev. Hasan Kamil Yılmaz. İstanbul: Altınoluk Yayınları, 1996.

Şahin, Kâmil. “19. ve 20. Yüzyılda Adana İslam Sıbyan Mektepleri Üzerinde Gözlemler". II. Uluslararası Karacaoğlan-Çukurova Halk Kültürü Sempozyumu. 445-456. Adana: Çukurova Üniversitesi Basımevi, 1993.

Şişman, Adnan. "Galatasaray Mekteb-i Sultânîsi”. Türkiye Diyânet Vakfi İslâm Ansiklopedisi. 13/323-326. İstanbul: TDV Yayınları, 1996.

Tahralı, Mustafa. "Ken'ân Rifâî". Türkiye Diyanet Vakfi İslam Ansiklopedisi. 25/254255. İstanbul: TDV Yayınları, 2002.

Tekeli, İlhan. “Osmanlı İmparatorluğu'ndan Günümüze Eğitim Kurumlarının Gelişimi". Cumhuriyet Dönemi Türkiye Ansiklopedisi. 3/657.İstanbul: İletişim Yayınları, 1983.

Uludağ, Süleyman. “Riyâzet”. Türkiye Diyanet Vakfı İslam Ansiklopedisi. 35/143-144. İstanbul: TDV Yayınları, 2008.

Yalçınkaya, Arzu Eylül.Ken'an Rifầ̂'nin Mesnevî Sohbetleri:Üçüncü Cilt İkinci Defter. İstanbul: İstanbul Üniversitesi, Sosyal Bilimler Enstitüsü, Yüksek Lisans Tezi, 2012.

Yüksel, Aydın. “Ümmü Ken'ân Tekkesi”. Dünden Bugüne İstanbul Ansiklopedisi. 6/111-112. İstanbul: Kültür Bakanlığ1 ve Tarih Vakfı Ortak Yayını, 1994.

\section{Arşiv Belgeleri}

BOA., DH.SAID., 58.23.

BOA., DH.SAID., 72.405.

BOA., İDH., 1221.95580. 
BOA., I...MF., 6.58.

BOA., MF.MKT., 159.125.

BOA., MF.MKT., 173.110.

BOA., MF.MKT., 562.36 .

BOA., MF.MKT., 842.23.

BOA., MF.MKT., 905.49.

BOA., MF.MKT., 1067.13.

\section{Kisaltmalar}

BOA. Başbakanlık Osmanlı Arşivi,

DH. SAID Dâhiliye Nezâreti Sicill-i Ahval Defteri

İ.DH. İradeler Dâhiliye

İ.MF. İrade Maârif

MF.MKT. Maârif Mektubî Kalemi 